\title{
Could cord blood cell therapy reduce preterm brain injury?
}

\author{
Jingang Li ${ }^{1}$, Courtney A. McDonald ${ }^{1}$, Michael C. Fahey ${ }^{1,2}$, Graham Jenkin ${ }^{1,3}$ and Suzanne L. Miller ${ }^{1,3} *$ \\ ${ }^{1}$ The Ritchie Centre, MIMR-PHI Institute, Clayton, VIC, Australia \\ ${ }^{2}$ Department of Paediatrics, Monash University, Clayton, VIC, Australia \\ ${ }^{3}$ Department of Obstetrics and Gynaecology, Monash University, Clayton, VIC, Australia
}

\section{Edited by:}

Gavin John Clowry, Newcastle

University, UK

Reviewed by:

Paulo Henrique Rosado De Castro,

Universidade Federal do Rio de

Janeiro, Brazil

Emily Camm, University of

Cambridge, UK

*Correspondence:

Suzanne L. Miller, Department of Obstetrics and Gynaecology, The

Ritchie Centre, MIMR-PHI Institute,

Monash University, Level 3, 27-31

Wright Street, Clayton, VIC 3168,

Australia

e-mail: suzie.miller@monash.edu
Major advances in neonatal care have led to significant improvements in survival rates for preterm infants, but this occurs at a cost, with a strong causal link between preterm birth and neurological deficits, including cerebral palsy (CP). Indeed, in high-income countries, up to $50 \%$ of children with CP were born preterm. The pathways that link preterm birth and brain injury are complex and multifactorial, but it is clear that preterm birth is strongly associated with damage to the white matter of the developing brain. Nearly $90 \%$ of preterm infants who later develop spastic CP have evidence of periventricular white matter injury. There are currently no treatments targeted at protecting the immature preterm brain. Umbilical cord blood (UCB) contains a diverse mix of stem and progenitor cells, and is a particularly promising source of cells for clinical applications, due to ethical and practical advantages over other potential therapeutic cell types. Recent studies have documented the potential benefits of UCB cells in reducing brain injury, particularly in rodent models of term neonatal hypoxia-ischemia. These studies indicate that UCB cells act via antiinflammatory and immuno-modulatory effects, and release neurotrophic growth factors to support the damaged and surrounding brain tissue. The etiology of brain injury in pretermborn infants is less well understood than in term infants, but likely results from episodes of hypoperfusion, hypoxia-ischemia, and/or inflammation over a developmental period of white matter vulnerability. This review will explore current knowledge about the neuroprotective actions of UCB cells and their potential to ameliorate preterm brain injury through neonatal cell administration. We will also discuss the characteristics of UCB-derived from preterm and term infants for use in clinical applications.

Keywords: preterm birth, low birth weight, brain damage, white matter injury, oligodendrocytes, cerebral palsy, umbilical cord blood, stem cells, hypoxia-ischemia, inflammation, periventricular leukomalacia

\section{BACKGROUND}

Impressive advances in perinatal and neonatal care have led to substantial improvements in survival rates for preterm infants born at $<37$ weeks gestation. However, survival of preterm infants may occur at a cost, with a strong causal link between preterm birth and subsequent neurological motor and cognitive deficits, including cerebral palsy $(\mathrm{CP})$. In particular, more extremely preterm babies now survive than ever before with these infants at the greatest risks of short and long-term neurodevelopmental deficits (1). Despite the known etiological link between preterm birth and neuromotor and neuro-cognitive dysfunctions, there are currently no specific neuroprotective treatments available for preterm infants.

Stem, or stem-like cells, have drawn attention from scientists and the general public due to their potential to induce tissue repair and/or regeneration. Umbilical cord blood (UCB)-derived cells offer ethical and practical advantages over other stem-like cells given that collection can be obtained from the discarded placenta at birth. Such cells possess multiple proven [as per cord blood hematopoietic stem cells (HSCs)] and potential therapeutic uses, including recent evidence that UCB cells may mitigate newborn brain damage arising from term neonatal hypoxicischemic encephalopathy (HIE). However, despite the heightened neurological risks associated with preterm births, the potential use of UCB cells in preterm neonates has not yet been actively investigated. This article briefly describes the background, etiology, and pathophysiological mechanisms of brain injury in preterm infants, and summarizes current research on the use of UCB cells for therapeutic use in term and preterm perinatal brain injury. Potential implications for future clinical trials of UCB cell therapy in preterm infants are discussed.

PRETERM BIRTH AND CHILDHOOD NEUROLOGICAL DEFICITS In 2010, 14.9 million babies worldwide were born preterm, accounting for approximately $11 \%$ of all births, with the rates and burden of preterm birth significantly increased in both low and high-income birth settings compared to the previous decade (2). Of all preterm births in the developed world, $16 \%$ are born before 32 weeks of gestation or weigh $<1500 \mathrm{~g}(2)$, with this population of very preterm infants (born 28 to $<32$ weeks) or extremely preterm infants $(<28$ weeks) at the greatest risks for long-term physical and neurological morbidities. Indeed, in developed countries, preterm births account for $70 \%$ of neonatal deaths and up to $75 \%$ of neonatal morbidity (3), with the risks of death or disability profoundly increased in middle- or low-income birth settings, reflecting decreased resources for neonatal intensive care (4). In addition, in developed countries most preterm babies now survive 
as a result of advances in neonatal intensive care such that the survival rate for extremely preterm infants is $90 \%$ (2).

Cerebral palsy is the most common physical disability of childhood, occurring in 2-2.5/1000 live births in developed countries. This rate is increased to approximately 90-100/1000 babies that were born at $<32$ weeks gestation $(5,6)$. Indeed, $35-50 \%$ of children with established CP were born preterm $(7,8)$. The major overt neurological manifestations of brain injury observed in children that were born preterm are spastic motor deficits, commonly accompanied by intellectual deficits. Less severe disturbances of motility, cognition, and behavior occur in $25-50 \%$ of survivors (9).

The economic cost of preterm birth and CP are high due to the need for neonatal intensive care and ongoing long-term complex health care. The National Institute of Medicine estimated that the lifetime cost of all preterm births is $\$ 26.2$ billion USD per year in the USA (10). The financial burden of CP in the USA has been separately costed and estimated at $\$ 11.5$ billion USD (11) and is indicative of the large financial burden association with preterm birth and CP. This is in addition to the significant burden placed on families and society who care for children and adults with CP. There is therefore an enormous demand to prevent or reduce brain injury in preterm infants, to reduce the subsequent neurodevelopmental sequelae, and consequently decreasing the large socio-economical burden.

The complications associated with preterm birth and brain injury are complex and involve multiple overlapping adverse pathways, but it is clear that preterm birth is strongly associated with damage to the white matter of the immature brain. Therefore, an understanding of white matter injury (WMI) is a critical component required for the treatment of preterm brain injury.

\section{WHITE MATTER INJURY}

Fetal brain maturation and functional development involves a series of organizational processes including neurogenesis, cell migration, cell differentiation, synaptogenesis, and axonal myelination. The development of white matter requires mature oligodendrocyte glial cells to produce myelin and ensheath the axons of neurons, and thus oligodendrocytes play a crucial role in fast signal transmission along neurons and throughout the brain. Injury to these cells impairs, usually irreversibly, myelination. Oligodendrocytes develop according to a well-defined lineage. Preoligodendrocytes are the predominating oligodendroglial cell at gestational age 24-32 weeks in humans. They are exquisitely vulnerable to pro-inflammatory cytokines, excitotoxicity, oxygen free radical attack, and hypoxic stress, and rapidly undergo apoptosis under adverse conditions (12-15). It is believed that this selective vulnerability of the pre-oligodendrocytes in preterm infants restricts the number and functional ability of mature oligodendrocytes to undergo the process of laying down of white matter and formation of myelin fibers, thus causing very preterm and extremely preterm infants to be most susceptible to WMI $(9,16$, 17). Thus, preserving oligodendrocytes and their precursor cells is fundamental to reducing injury to the developing white matter of the brain. Most commonly, preterm brain injury is evident in the periventricular white matter adjacent to the lateral ventricles, so-called periventricular leukomalacia (PVL). WMI is detectable in at least $50 \%$ of infants born very preterm or extremely preterm, and is a strong indicator of long-term neurological adverse outcome. Nearly $90 \%$ of preterm infants who later develop spastic CP have evidence of WMI (9). Half of the children identified as having WMI will have cognitive and/or behavioral and/or attention deficits (18-20). Clinical imaging studies demonstrate that myelin loss (hypomyelination) and disorganization of major white matter fiber tracts correlate with functional impairments in children with CP and PVL $(21,22)$.

Pathologically, WMI is a condition demonstrated by coagulation and necrosis of white matter near the lateral ventricles, accompanied by gliosis (23). The periventricular area is vulnerable to ischemia in the preterm brain, which, in part, is anatomically due to poor vascularization and immature cerebrovascular autoregulation $(24,25)$. This may result in focal PVL. But, in many cases, WMI is widespread and incorporates periventricular, subcortical, and callosal white matter, as well as the internal capsule. WMI, and in particular PVL, has two distinct histopathological appearances, described as either cystic or non-cystic (diffuse) WMI. Cystic WMI typically affects all types of cells and is therefore considered the more severe type and is closely linked with CP, whereas diffuse PVL mainly targets pre-oligodendrocytes and is considered less severe but nonetheless is linked to cognitive and behavioral impairments, and CP (9). It is generally considered that the gray matter is not as susceptible to preterm insults as is white matter, but the pre-oligodendrocytes also present in gray matter are not spared, leading to damage involving the cerebral cortex, thalamus, and basal ganglia $(26,27)$.

There is a growing understanding of the etiology of preterm brain injury, likely involving one or more interactions between fundamental immaturity of the brain, vulnerability of white matter developmental processes, and the adverse effects of two principal upstream insults: hypoxia-ischemia and infection/ inflammation. Hypoxia-ischemia and infection/inflammation are relatively common in the preterm period, and have profound adverse effects on white matter development (28-30).

\section{HYPOXIA-ISCHEMIA AND WHITE MATTER INJURY}

After an hypoxic-ischemic insult, microglia and macrophages within the brain's white matter exhibit immunoreactivity for interleukin-6 (IL-6) and tumor necrosis factor- $\alpha$ (TNF- $\alpha$ ), and infiltrate to lesion sites. Astrocytes become hypertrophied and diffuse gliosis is evident within $24 \mathrm{~h}$. Loss of oligodendroglial lineage cells and impairment of myelinogenesis is evident within 10 days following hypoxia-ischemia $(9,31-35)$. When the insult has been prolonged or severe, brain injury is exacerbated through influx of cytokines and chemokines via the damaged blood-brain-barrier (BBB), thereby further increasing inflammatory mediators within the brain (36).

In response to a significant hypoxic-ischemic insult, secondary pathways of injury are also initiated and evolve over days. These adverse pathways include mitochondrial dysfunction, excitotoxicity, apoptosis, oxidative stress, and initiation of additional inflammatory processes (37). A further adverse effect of hypoxiaischemia is the disruption of normal growth and differentiation factors driving brain development, decreasing concentrations of signaling proteins and nutrients that include neurotrophic factors vital for inhibition of programed cell death $(38,39)$. For example, 
brain-derived neurotrophic factor (BDNF), neurotrophin-3 (NT3 ), and NT-4/5 play important roles in promoting neuronal growth and differentiation, connective plasticity, and neuronal survival through their interaction with tyrosine kinase $\beta$-receptors, but these are each affected in the preterm brain in response to hypoxiaischemia (40). Additional neuron and glial cell loss occurs over days and weeks after a sentinel insult, resulting from chronic deprivation of neurotrophic factors, decreased synaptic input from neighboring cells, and loss or recruitment failure of local neural and glial stem and progenitor cells $(41,42)$. The severity and duration of neurotrophic factor deprivation directly correlates to long-term neurological outcome $(38,42)$.

In addition, activated astrocytes and microglia mediate the release of reactive oxygen species (ROS) and reactive nitrogen species (RNS), leading to increased protein nitration and oxidative stress in response to hypoxia-ischemia and brain inflammation (43). In the context of preterm birth, a compromised intrauterine environment may induce excess release of free radicals and, combined with the transition to an extra-uterine high oxygen environment, may overwhelm endogenous antioxidant enzymes, resulting in preferential death of pre-oligodendrocytes and contributing to the development of WMI within the preterm brain (43-46).

\section{INFECTION/INFLAMMATION AND WHITE MATTER INJURY}

Fetal and neonatal exposure to infection and/or inflammation is recognized as a principal contributor to preterm birth and WMI. Maternal intrauterine infection including chorioamnionitis is associated with increased levels of pro-inflammatory cytokines (IL-6, IL-8, TNF- $\alpha$, and IL-1b) in the amniotic fluid and cord blood (47-49) and is one of the most important causes of preterm birth $<30$ weeks of gestation (50). Maternal intrauterine infection presents a significant risk for WMI and CP $(51,52)$. Neonatal sepsis is also a risk factor for WMI in infants that were born preterm $(53,54)$.

Adverse inflammatory stimuli during fetal or neonatal life induce a systemic and central nervous system (CNS) response via activation of innate and adaptive immune systems. Microglia are the primary mediators of the brain's immune response, mediating the pro- and anti-inflammatory response to remove pathogens, via binding of toll-like receptors (TLRs) with ligands, pathogen-associated molecular patterns (PAMPs), and/or danger-associated molecular patterns (DAMPs) (55, 56). However, prolonged microglial activation can cause brain injury (55). Microglia are at their peak density in white matter during the WMI-vulnerable period (57), making them fundamental in producing WMI (44). Lipopolysaccharide (LPS), an endotoxin of gram-negative bacteria and a form of PAMP, and binds receptors including TLR-4 and CD14 on microglia, initiating a signal transduction cascade that ultimately activates transcription factors such as nuclear factor-kappaB (NF-кB). In turn, this leads to up-regulation of cytokines, chemokines, and complement proteins, and over time this response can sensitize the developing brain to secondary insults thereby contributing to sustained CNS inflammation. Cytokines may directly act upon oligodendrocytes to induce cell death, as evidenced by in vitro studies on human oligodendrocytes where TNF- $\alpha$ and interferon- $\gamma$ (IFN- $\gamma$ ) induced dose-dependent cell necrosis (58). In vivo administration of highdose LPS to preterm fetal sheep results in significant cerebral hemodynamic changes that cause cerebral ischemia and PVL-like fetal brain injury (59), while low-dose LPS, insufficient to cause fetal hypoxia, induces diffuse WMI and microglial invasion, where the degree of microglial activation is correlated to the presence of WMI (60).

The downstream pathways that result from hypoxia-ischemia, or inflammatory stimuli, are complex and are not mutually exclusive. Hypoxia-ischemia and increased ROS are known to induce an inflammatory reaction and, conversely, pro-inflammatory mediators lead to the generation of free radicals and oxidative stress. This interaction is driven by NF- $\kappa \mathrm{B}$. In normal-state resting cells, the NF- $\kappa$ B protein complex remains within the cytoplasm, bound

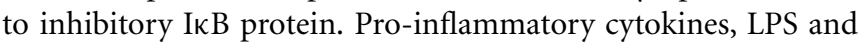
viruses cause proteolysis of $\mathrm{I} \kappa \mathrm{B}$, allowing dissociation from NF$\kappa \mathrm{B}$, and the nuclear translocation of NF- $\kappa \mathrm{B}$ where it activates gene transcription (61). Additionally, tissue hypoxia and oxidative stress can modulate NF- $\kappa$ B release (61). Thus, hypoxia-ischemia can induce inflammation via microglial activation, and conversely infection/inflammation can induce hypoxia-ischemia through hypotension (62). Indeed, preterm infants have been shown to have higher risk of WMI when chorioamnionitis and placental perfusion deficits are present together (63).

\section{LIMITATIONS OF CURRENT TREATMENTS OF WHITE MATTER INJURY}

Although there have been major clinical and scientific advances in neonatal care over the last decade, currently only antenatal corticosteroid are proven to reduce the risk of intraventricular hemorrhage (IVH) (64). Other strategies in preterm infants, such as use of erythropoietin, melatonin, indomethacin, antenatal magnesium sulfate, therapeutic hypothermia, or delayed cord clamping remain at the experimental investigation stage and are not of proven benefit $(65,66)$. Thus, current management for preterm brain injury has, until now, been restricted to supportive strategies.

One of the biggest hurdles for identifying neuroprotective strategies for preterm infants is the multi-faceted etiology of the brain damage. As described in the section above, the primary antenatal causal factors that may induce brain injury include maternal/fetal infection and/or chronic placental perfusion insufficiency $(67,68)$. Postnatal factors may exacerbate or cause brain injury, including repetitive subacute/chronic hypoxia-ischemia due to poor lung function and ventilation, and free radical imbalance following oxygen reperfusion in response to a high oxygen extra-uterine environment or oxygen administration $(44,46,69)$. Neonatal chronic cerebral hypoperfusion, hypotension, hypocarbia, or symptomatic persistent ductus arteriosus $(70,71)$, IVH with or without post-hemorrhagic ischemia or hydrocephalus (72), infection $(53,54)$, hypoglycemia, and glucocorticoid administration are also involved in the progression of brain injury (68, 73). Moreover, even preterm birth without exacerbating factors can result in subtle white matter pathology (69). Thus, it can be appreciated that unlike term neonatal HIE, these insults do not necessarily occur around the time of delivery, and it may therefore be difficult to recognize the timing of the onset of a sentinel (or 
exacerbating) insult. It would therefore be likely that preterm brain injury would be best treated with a therapy, or therapies, with multiple neuroprotective mechanisms and with a long therapeutic window. Any therapy should be targeted at WMI as the predominant neuropathology. Additionally, such a treatment would be aimed at one or more of the following - reducing inflammation and free radical attack, halting the progression of cell death programing, and/or replacing damaged oligodendrocytes in order to remodel areas of WMI and normalize myelination. We will present data to support the therapeutic potential of neonatally administered UCB-derived cells, for protection and repair of the preterm brain.

\section{STEM CELLS}

Stem cells are characterized by their ability to undergo self-renewal and to differentiate into multiple cell types. In general, stem cells can be classified into three major categories on the basis of their source, namely embryonic stem cells (ESCs), fetal-derived stem cells, and adult stem cells. ESCs are pluripotent, are able to generate cells from all three germ layers and can be maintained in culture indefinitely (74), providing a limitless source of precursor cells for the regeneration of damaged tissue. However, due to the pluripotent nature of ESCs they are also tumorigenic and transplantation of these cells currently presents significant safety concerns (75), and has cautioned their use in clinical trials. ESCs are also obtained from embyros, presenting ethical issues. With recent advances, it has become possible to reprogram somatic cells and generate induced pluripotent stem (iPS) cells (76). These cells may be able to overcome some of the limitations of ESCs, i.e., ethical issues, and enable the generation of patient-specific iPS cell lines. However, they are also tumorigenic (77), and this issue remains unresolved. Adult stem cells, or stem-like cells, include mesenchymal stromal cells (MSCs), that can be obtained from a number of sources including bone marrow, adipose tissue, and dental pulp, and neural progenitor cells (NPCs) that are found in the subventricular zone of the brain and comprise multipotent stem/progenitor cells that can differentiate down the neural lineage, including to neurons and glial cells (78). NPCs can be isolated from the adult brain and expanded for several passages whilst retaining their undifferentiated state. Lastly, fetal-derived stem-like cells can be obtained from placental tissue (79) and UCB (80) and include placental and umbilical cord MSCs (UC-MSCs), amnion epithelial cells (AECs), HSCs, and endothelial progenitor cells (EPCs) (81). Given these cells are isolated from fetal tissue, they tend toward greater differentiation and expansion potential than adult stem cells. Fetal-derived stem cells can be easily isolated from tissue that is routinely discarded at birth, they are abundant due to the large number of births each year, and their collection raises no ethical concerns.

Stem-like cells sourced from placenta and umbilical cord (UC) have been studied pre-clinically for treatment of a variety of diseases including multiple sclerosis $(82,83)$, stroke $(84,85)$, bronchopulmonary dysplasia $(86,87)$, and $\mathrm{CP}(88,89)$ and may be beneficial for reducing disease burden in these conditions. For MSCs alone, there are currently $>400$ clinical trials listed on clinical trials.gov (search: "mesenchymal stem cell"). However, there are numerous clinics around the world that are already capitalizing on the promise of stem cell treatment and are offering stem cell therapies for financial gain to families of those with conditions including CP. This has been coined stem cell tourism (90). It is therefore imperative that well-planned and controlled pre-clinical and clinical trials are conducted to establish the safety, short-, and long-term efficacy, and mechanisms by which stem cell therapies may provide benefit, which in turn will enable treating clinicians and patients to make informed decisions regarding the use of stem cell treatments.

\section{UMBILICAL CORD BLOOD}

Umbilical cord blood is a rich source of HSCs, accounting for $0.5-1.0 \%$ of mononuclear cells (MNCs) in term UCB (91), used to treat patients with abnormal hematopoietic conditions, childhood leukemia, or metabolic diseases (92). HSCs are positive for CD34 and CD45, and defined by their capacity to self-renew and give rise to multiple blood lineages. Traditionally, bone marrowderived HSCs were used to treat these conditions, however, UCB is easier to obtain, less expensive and less likely to trigger a deleterious immune response or rejection in the recipient (93). HSCs from human UCB (hUCB) are also more primitive than bone marrow-derived HSCs, have longer telomeres, have a higher colony-forming capacity and can repopulate blood lineages over a long period of time $(94,95)$. Given these advantages, more than 3000 hUCB transplants are now performed each year for blood and other disorders (96). Other strong advantages for the use of UCB for transplants include that it can be tissue typed, screened for viral biomarkers, processed and banked, allowing the supply for both urgent and directed transplants (97) and the volume and number of cells that can be attained is generally very good. In term births, a large volume of UCB can be collected [38-42 weeks: $102 \pm 30 \mathrm{ml}$, containing $11.3 \pm 6.2 \times 10^{8}$ total nucleated cell (TNC)] (91). However, in preterm birth, or in pregnancy complications [such as intrauterine growth restriction (IUGR)], there is reduced UCB volume for collection [34-37 weeks: $90 \pm 32 \mathrm{ml}, 7.7 \pm 4.8 \times 10^{8} \mathrm{TNC}$; 25-33 weeks: $62 \pm 31 \mathrm{ml}, 3.3 \pm 3.5 \mathrm{TNC}$ ] (91), which is problematic if UCB collection is required or requested. Furthermore, it is not known how antenatal complications, such as IUGR or chorioamnionitis, may change the composition of the stem and stem-like cells present in the UCB, and whether differences in cell composition may impact its therapeutic utility.

Umbilical cord blood is not only a useful source of HSCs, but also contains a number of other stem/progenitor cell types including MSCs and EPCs (80). Moreover, UCB is a rich source of immunosupressive cells, such as regulatory T cells (Tregs) (98). MSCs are multipotent adult progenitor cells that have a broad potential for repair of injured tissue. MSCs are characterized by their morphology, phenotype, and differentiation potential to form osteoblasts, chondrocytes, and adipocytes (82). MSCs are a plastic adherent cell population with the absence of CD34, CD45, and CD133, and are positive for CD13, CD29, CD44, CD73, and CD90 (80, 99). MSCs can indeed be isolated from UCB, but at a very low frequency and cellular fraction, with success rates for isolation ranging from 40 to $60 \%(99,100)$ and, in one study, only $8 \%$ of UCB units could be effectively expanded into MSClike colonies (100). While the frequency of MSCs is low in UCB $(0.002 \%$ of MNCs in term UCB) (101), UCB-MSCs show a strong 
proliferation capacity and can be maintained longer in culture than MSCs derived from other sources (99). Furthermore, following exposure to neural differentiation factors, hUCB-MSCs express a number of neural cell antigens, including glial fibrillary acidic protein (found in astrocytes), TuJ-1 (neural progenitor), vimentin, and nestin (102).

Endothelial progenitor cells, isolated from bone marrow, peripheral blood, and UCB can be differentiated into mature endothelial cells in vitro and, in animal models of ischemia, can incorporate into sites of active angiogenesis to stabilize and promote the growth of new blood vessels (103). While EPC classification remains contentious, they are generally characterized by the expression of CD133, CD34, and vascular endothelial growth factor (VEGF) receptor-2 (104). EPCs are estimated to make up $1-2 \%$ of HSC-containing CD34+ cell fraction in term UCB, representing 1 in $10^{7}$ MNCs (105). Despite the low number, EPCs isolated from hUCB have been shown to have a stable endothelial phenotype and a higher proliferative capacity compared to those isolated from peripheral blood, making UCB a superior source for the isolation of EPCs. Studies are now being conducted to optimize the isolation of the three major cell types (EPCs, HSCs, and MSCs) from single UCB units (80).

Regulatory $\mathrm{T}$ cells should also be considered as potential useful cells to be isolated from UCB. Tregs are immunosupressive $\mathrm{T}$ cells that can maintain self-tolerance, prevent autoimmunity, inhibit rejection of transplants, and regulate the immune response to infectious disease (106). Tregs isolated from UCB exhibit a predominantly naïve phenotype, which is associated with a significantly enhanced proliferative potential compared to adult Tregs (107). It has been suggested that the low incidence of graftversus-host-disease (GVHD) associated with UCB transplants is due to the presence of Tregs (108), adding to their importance for UCB transplants and their potential utility for treatment of inflammatory conditions.

Optimal selection of UCB units for HSC transplants includes determination of TNC content, CD34+ cell count, and HLA and blood group matching of the recipient and donor (97). However, there is sparse information related to other cells of interest within UCB. Given the increasing likelihood that children born preterm may request autologous UCB cell collection and treatment for brain injury (see below), it is imperative that we investigate the similarities and differences between term and preterm UCB. This knowledge will inform the design of clinical trials that will decide whether autologous or allogeneic UCB transplants will be best placed to treat neurological impairments in preterm-born infants. To date, it has been shown that the frequency of CD34+ cells in preterm neonates was twofold increased compared to those in term neonates (109) and, for a given gestational age, each $500 \mathrm{~g}$ increase in birth weight contributed to a $28 \%$ increase in CD34+ cell counts (110). In preterm infants, the immunophenotypic profile of UCBCD34+ cells shows a significantly higher expression of CD33, and a lower expression of CD38, CD117, and HLA-DR, indicating preterm UCB has a higher percentage of primitive CD34+ subsets, while term UCB has a higher percentage of committed cells (111, 112). With specific regard to EPCs, preterm (28-34 weeks) UCB units have a fourfold increase in endothelial colony-forming cells compared to term UCB (113). However in compromised placental conditions such as preeclampsia, EPCs are decreased in term UCB, and not different to those in preterm UCB (114). Similar to other cell types, MSC population is also richer in preterm UCB compared with term, with a significant inverse correlation between the gestational age and presence of MSCs $(101,115)$. Furthermore, studies to date have predominantly assessed cell number and not cell function over gestation, where functionality may be a more important marker of efficacy than absolute cell number. As has been shown with hAECs, while preterm cells have a high proliferative capacity, they are functionally immature and cannot differentiate into other cell types (116). The presence of Tregs has also been assessed over gestation, and is reportedly increased in preterm UCB compared to term UCB (107), but Tregs from preterm UCB secrete significantly less IFN- $\gamma$ (117). Furthermore, Tregs in UCB from IUGR infants at term were decreased compared to those in UCB units from appropriately grown babies (118).

Most studies to date examining perinatal brain injury have utilized UCB-MNCs (Table 1), but UCB-MNCs is composed of a variety of cells of interest including immature $\mathrm{T}$ cells, Bcells, monocytes, and stem-like cells including HSCs, EPCs, and MSCs. The fraction or combination of UCB cells responsible for neural repair remains to be established. UCB-MSCs have attracted interest for some time because of their multilineage differentiation potential, strong capacity for immune modulation, and low immunogenicity. Indeed, expanded hUCB-MSC transplantation has shown promise in protecting against perinatal brain injury in pre-clinical animal studies (119-121). Despite this, the clinical application of purified UCB-MSCs is currently limited by their low numbers and low success rate for isolation. On the other hand, CD34+ cells have been shown to reduce brain injury in neonatal hypoxic-ischemic mice, with a transient augmentation of cerebral blood flow in the peri-infarct area (122). UCB-CD133+ cells, the fraction enriched for EPCs and HSCs, also reduces infarct volume in a rat model of stroke (123).

In addition to stem-like cells, other cellular fractions in UCB have also been shown to have potentially important neuroprotective roles. When hUCB-MNCs was depleted for CD14+ monocytes, there was no decrease observed in microglial activation or functional recovery following administration (124), suggesting that monocytes are essential for mediating the neuroprotective benefits of hUCB cells in hypoxic-ischemic rats. In addition, a further study showed that a single injection of hUCB-derived $\mathrm{T}$ cells (CD4+) induced endogenous NPC proliferation for 2 weeks and promoted increased neuronal cell survival in rats (125). The therapeutic effects of stem cells are now thought to be independent of tissue engraftment $(89,126-129)$, although many studies have shown that transplanted UCB cells can migrate selectively toward ischemic areas of damaged brain $(127,130)$. It is widely considered that regenerative effects of stem cells are principally derived from indirect paracrine and trophic effects, and increasing the regenerative capacity of the brain, rather than via direct cell replacement $(38,128,129,131,132)$. However, it is important to note that the studies referred to above have utilized hUCB in a xenogeneic setting. As such, the ability of the transplanted cells to survive and differentiate may be compromised (133). To our knowledge, the ability of autologous UCB cells to home to the site of injury and differentiate into neurons or neuroglial cells has not 


\begin{tabular}{|c|c|c|c|c|c|c|c|c|c|c|c|c|}
\hline \multirow[t]{2}{*}{ Cell type } & \multirow{2}{*}{$\begin{array}{l}\text { Animal model } \\
\text { Injury type }\end{array}$} & \multicolumn{3}{|c|}{ Administration } & \multicolumn{2}{|r|}{ Engraftment } & \multicolumn{2}{|c|}{ Histology assessments } & \multicolumn{2}{|c|}{ Functional assessments } & \multirow[t]{2}{*}{ Other } & \multirow[t]{2}{*}{ Reference } \\
\hline & & Timing & Dose & Route & Days & Results & Days & Outcomes & Days & Outcomes & & \\
\hline \multirow[t]{10}{*}{$\begin{array}{l}\text { hUCB- } \\
\text { MNCs }\end{array}$} & $\begin{array}{l}\text { P7 rats, HI } \\
80 \text { min }\end{array}$ & $\begin{array}{l}24 \mathrm{~h} \\
\text { after } \mathrm{HI}\end{array}$ & $\begin{array}{l}1 \times 10^{7} \\
\text { cells }\end{array}$ & $\mathrm{IP}$ & 21 days & $\begin{array}{l}\text { Many cells in ischemic } \\
\text { hemisphere. No sign of } \\
\text { transdifferentiation }\end{array}$ & NA & NA & 21 days & $\begin{array}{l}\text { Alleviation of spastic } \\
\text { paresis }\end{array}$ & & $\begin{array}{l}\text { Meier } 2006 \\
\text { (127) }\end{array}$ \\
\hline & $\begin{array}{l}\text { P7 rats, HI } \\
120 \mathrm{~min}\end{array}$ & $\begin{array}{l}24 \mathrm{~h} \\
\text { after } \mathrm{HI}\end{array}$ & $\begin{array}{l}1 \times 10^{7} \\
\text { cells }\end{array}$ & IV jugular & 21 days & Few cells in brain tissue & 21 days & $\begin{array}{l}\text { No change in volume of } \\
\text { injured hemisphere }\end{array}$ & 21 days & $\begin{array}{l}\text { No change on spatial } \\
\text { memory deficit }\end{array}$ & & $\begin{array}{l}\text { de Paula } \\
2009 \text { (192) }\end{array}$ \\
\hline & $\begin{array}{l}\text { P7 rats, HI } \\
90 \mathrm{~min}\end{array}$ & $\begin{array}{l}3 \mathrm{~h} \text { after } \\
\mathrm{HI}\end{array}$ & $\begin{array}{l}2 \times 10^{6} \\
\text { cells }\end{array}$ & IP & 2 days & $\begin{array}{l}\text { Few cells in ischemic } \\
\text { cortex and striatum }\end{array}$ & 2 days & $\begin{array}{l}\text { Decreased neuronal } \\
\text { death in striatum, and } \\
\text { microglial activation in } \\
\text { cortex }\end{array}$ & 4,7 days & $\begin{array}{l}\text { Improved developmental } \\
\text { sensorimotor reflexes } \\
\text { only at } 4 \text { days }\end{array}$ & & $\begin{array}{l}\text { Pimentel- } \\
\text { Coelho } \\
2010(134)\end{array}$ \\
\hline & $\begin{array}{l}\text { P7 rats, HI } \\
\text { 150min }\end{array}$ & $\begin{array}{l}2-3 \mathrm{~h} \\
\text { after } \mathrm{HI}\end{array}$ & $\begin{array}{l}1.5 \times 10^{4} \\
\text { cells }( \pm \\
\text { mannitol) }\end{array}$ & IV jugular & 14 days & $\begin{array}{l}\text { Few cells in ischemic } \\
\text { hippocampus }\end{array}$ & NA & NA & 7, 14 days & $\begin{array}{l}20-25 \% \text { improvement in } \\
\text { rotarod and elevated body } \\
\text { swing tests }\end{array}$ & $\begin{array}{l}\text { Increased growth } \\
\text { factors in brain, CA1 } \\
\text { dendrites }\end{array}$ & $\begin{array}{l}\text { Yasuhara } \\
2010 \text { (138) }\end{array}$ \\
\hline & $\begin{array}{l}\text { P7 rats, HI } \\
80 \mathrm{~min}\end{array}$ & $\begin{array}{l}24 \mathrm{~h} \\
\text { after } \mathrm{HI}\end{array}$ & $\begin{array}{l}1 \times 10^{7} \\
\text { cells }\end{array}$ & IP & 42 days & $\begin{array}{l}\text { Many cells in peri-infarct } \\
\text { area }\end{array}$ & 42 days & $\begin{array}{l}\text { No change in size of } \\
\text { hemispheric lesion }\end{array}$ & 42 days & $\begin{array}{l}\text { Improved sensorimotor } \\
\text { function, cortical maps, } \\
\text { and receptive fields, and } \\
\text { reduced hyperexcitability }\end{array}$ & & $\begin{array}{l}\text { Geissler } \\
2011 \text { (135) }\end{array}$ \\
\hline & $\begin{array}{l}\text { P7 rats, HI } \\
80 \text { min }\end{array}$ & $\begin{array}{l}24 \mathrm{~h} \\
\text { after } \mathrm{HI}\end{array}$ & $\begin{array}{l}1 \times 10^{7} \\
\text { cells }\end{array}$ & $\mathrm{IT}$ & 14 days & $\begin{array}{l}\text { hUCB cells were localized } \\
\text { in astrocyte-rich zone }\end{array}$ & $\begin{array}{l}2,14 \\
\text { and } \\
44 \text { days }\end{array}$ & $\begin{array}{l}\text { Decreased activation of } \\
\text { microglia/macrophages } \\
\text { and reactive } \\
\text { astrogliosis, and } \\
\text { reduced peri-lesional } \\
\text { astrocytic wall }\end{array}$ & $\begin{array}{l}14,44 \\
\text { days }\end{array}$ & $\begin{array}{l}\text { Improved motor function } \\
\text { (forelimb use bias, } \\
\text { muscle strength and } \\
\text { distal spasticity) both } \\
\text { short- and long-term }\end{array}$ & $\begin{array}{l}\text { Downregulation of } \\
\text { Connexin } 43\end{array}$ & $\begin{array}{l}\text { Wasielewski } \\
2012 \text { (136) }\end{array}$ \\
\hline & $\begin{array}{l}\text { P7 rats, } \mathrm{HI} \\
80 \mathrm{~min}\end{array}$ & $\begin{array}{l}24 \mathrm{~h} \\
\text { after } \mathrm{HI}\end{array}$ & $\begin{array}{l}1 \times 10^{7} \\
\text { cells }\end{array}$ & IP & NA & NA & $\begin{array}{l}2, \\
14 \text { days }\end{array}$ & $\begin{array}{l}\text { Decreased } \\
\text { lesion-induced } \\
\text { apoptosis, increased } \\
\text { neurons }\end{array}$ & NA & NA & $\begin{array}{l}\text { Increased the } \\
\text { expression of } \\
\text { proteins Tie-2, } \\
\text { occludin, BDNF and } \\
\text { VEGF in the lesioned } \\
\text { brain }\end{array}$ & $\begin{array}{l}\text { Rosenkranz } \\
2012 \text { (141) }\end{array}$ \\
\hline & $\begin{array}{l}\text { P7 rats, HI } \\
120 \mathrm{~min}\end{array}$ & $\begin{array}{l}2 \mathrm{~h} \text { after } \\
\mathrm{HI}\end{array}$ & $\begin{array}{l}1 \times 10^{6} \\
1 \times 10^{7} \\
1 \times 10^{8} \\
\text { cells }\end{array}$ & IV jugular & 7 days & $\begin{array}{l}\text { Cells in the cortex and the } \\
\text { hippocampus }\end{array}$ & 8 weeks & $\begin{array}{l}\text { No change in low-dose } \\
\text { group. Decreased brain } \\
\text { atrophy in medium- and } \\
\text { high-dose groups }\end{array}$ & 8 weeks & $\begin{array}{l}\text { Cognitive improvement at } \\
\text { the highest dose only }\end{array}$ & & $\begin{array}{l}\text { de Paula } \\
2012 \text { (133) }\end{array}$ \\
\hline & $\begin{array}{l}\text { P7 rats, } \mathrm{HI} \\
90 \mathrm{~min}\end{array}$ & $\begin{array}{l}24 \mathrm{~h} \\
\text { after } \mathrm{HI}\end{array}$ & $\begin{array}{l}1 \times 10^{7} \\
\text { cells }\end{array}$ & IV jugular & $\begin{array}{l}1,3 \text {, and } \\
10 \text { weeks }\end{array}$ & $\begin{array}{l}\text { Many cells were in } \\
\text { ischemic periventricular } \\
\text { region at } 1 \text { week, but very } \\
\text { few at } 3 \text { and } 10 \text { weeks }\end{array}$ & 10 weeks & $\begin{array}{l}\text { No decrease in tissue } \\
\text { loss volume, decreased } \\
\text { neuronal loss in } \\
\text { neocortex }\end{array}$ & 10 weeks & $\begin{array}{l}\text { Improved performance in } \\
\text { a battery of behavioral } \\
\text { tests }\end{array}$ & & $\begin{array}{l}\text { Bae } 2012 \\
\text { (139) }\end{array}$ \\
\hline & $\begin{array}{l}\mathrm{P} 7 \text { rats, } \mathrm{HI} \\
120 \text { min } \\
(+ \text { cyclosporin } \mathrm{A})\end{array}$ & $\begin{array}{l}24 \mathrm{~h} \\
\text { after } \mathrm{HI}\end{array}$ & $\begin{array}{l}3 \times 10^{6} \\
\text { cells }\end{array}$ & IVen & NA & NA & $\begin{array}{l}24,72 \mathrm{~h}, \\
7, \\
14 \text { days }\end{array}$ & $\begin{array}{l}\text { Decreased neuronal } \\
\text { loss in cortex and CA1 } \\
\text { of the hippocampus }\end{array}$ & NA & NA & $\begin{array}{l}\text { Increased Shh and } \\
\text { Gli1 protein levels }\end{array}$ & $\begin{array}{l}\text { Wang } 2014 \\
(137)\end{array}$ \\
\hline $\begin{array}{l}\text { hUCB- } \\
\text { CD34+ }\end{array}$ & $\begin{array}{l}\text { P12 SCID mice, } \\
\text { MCAO }\end{array}$ & $\begin{array}{l}48 \mathrm{~h} \\
\text { after } \mathrm{HI}\end{array}$ & $\begin{array}{l}1 \times 10^{5} \\
\text { cells }\end{array}$ & IV femoral & $\begin{array}{l}24 \mathrm{~h} \\
10 \text { days }\end{array}$ & $\begin{array}{l}\text { Few cells at } 24 \mathrm{~h} \text {, very } \\
\text { few at } 10 \text { days }\end{array}$ & 7 weeks & Decreased brain atrophy & $\begin{array}{l}9 \text { days, } \\
7 \text { weeks }\end{array}$ & $\begin{array}{l}\text { No effect on rotarod or } \\
\text { open-field tests }\end{array}$ & $\begin{array}{l}\text { Transient } \\
\text { augmentation of } \\
\text { CBF in peri-infarct } \\
\text { area }\end{array}$ & $\begin{array}{l}\text { Tsuji } 2014 \\
\text { (122) }\end{array}$ \\
\hline
\end{tabular}




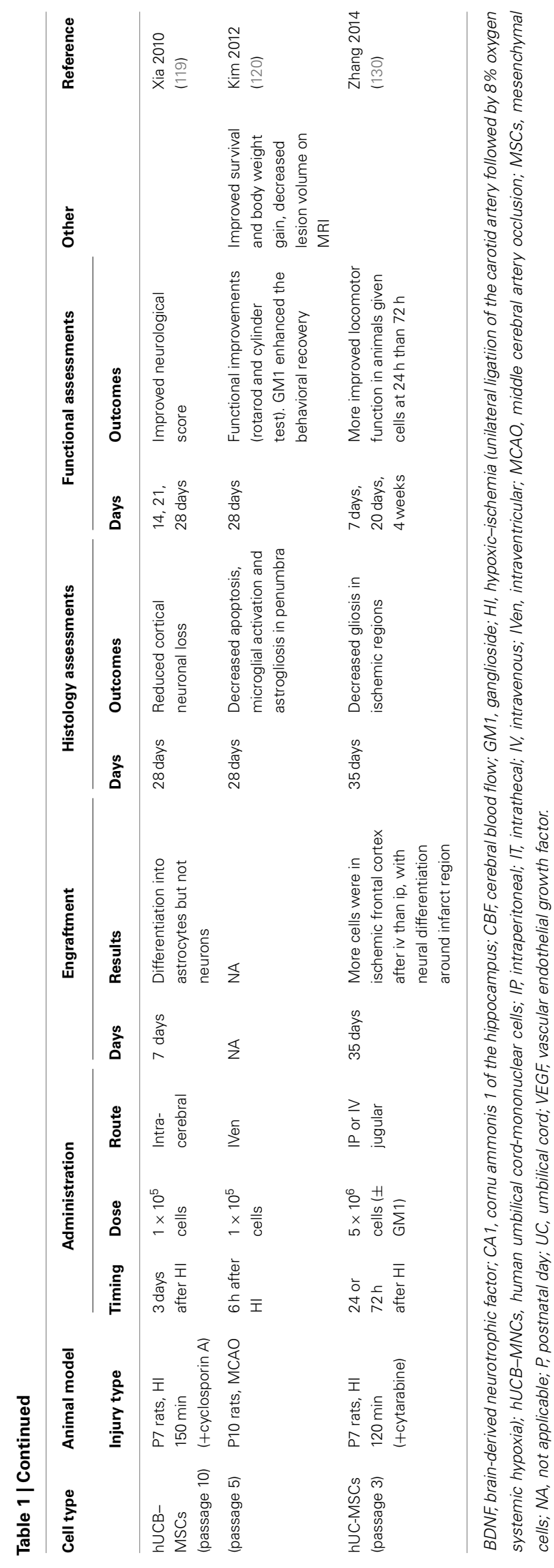

been investigated. Thus, the engraftment potential of UCB cells remains poorly characterized, and requires further investigation in studies using autologous transplantation.

\section{NEUROPROTECTIVE PROPERTIES OF UMBILICAL CORD BLOOD}

A number of studies have demonstrated significant and reproducible neuroprotective effects in rodent models of term neonatal hypoxia-ischemia using UCB-MNCs (127, 133-139), UCB-MSCs $(119,120)$, or UCB-CD34+ cells (122). Meier and colleagues first showed that intra-peritoneal administration of hUCB-MNCs alleviated spastic paresis in the Rice-Vannucci model of neonatal hypoxic-ischemic rats $(127,140)$. Following this, other rodent studies have shown that hUCB-MNCs induce significant improvements in sensorimotor performance $(134-136,138)$ and reduction in neuronal loss $(133,134,137-139,141)$. Recent studies also showed long-lasting neuroprotective effects of hUCB-MNCs in behavioral and cognitive outcomes at 8 and 10 weeks after ischemic insult $(133,139)$, with decreased brain atrophy (133). Animals treated with intra-cerebral hUCB-MSCs also demonstrated improved neurological function and tissue repair $(119,120)$.

From pre-clinical results obtained to date, we hypothesize that UCB cells may act in a neuroprotective manner via diverse actions, including anti-inflammatory effects, immunomodulation, and neurotrophic growth factor release to promote endogenous neurogenesis.

\section{ANTI-INFLAMMATORY AND IMMUNO-MODULATORY ACTIONS OF UMBILICAL CORD BLOOD}

A principal mechanism whereby UCB cells regulate neurological repair is via anti-inflammatory actions. UCB administration can dampen the expression of pro-inflammatory cytokines (IL$1 \alpha$, IL-6, IL-1 $\beta$, and TNF- $\alpha$ ), enhance anti-inflammatory cytokines (IL-10), secrete chemotactic proteins (monocyte chemotactic protein 1), and modulate immune macrophage and $\mathrm{T}$ cell function $(142,143)$. As described above, hypoxia-ischemia induces an acute brain inflammatory response with activation of microglia and macrophages and reactive astrogliosis associated with peri-lesional up-regulation of connexin 43, the major astrocytic gap junction protein (144). Administration of hUCB-MNCs normalizes inflammatory balance, reduces microgliosis and astrogliosis (134, 136), and down-regulates connexin 43 , which in turn restores BBB function to moderate inflammatory cell influx into the brain (136).

\section{NEUROTROPHIC FACTOR ACTIONS OF UMBILICAL CORD BLOOD}

Transplanted UCB-MNCs or MSCs reportedly enhance neurological recovery via secretion of a wide variety of trophic factors including BDNF, glial cell line-derived neurotrophic factor (GDNF), nerve growth factors NT-3 and NT-5, angiogenin, VEGF, fibroblast growth factor-2, and epidermal growth factor. Together, these act to promote endogenous neuronal growth and neurogenesis, angiogenesis, encourage remyelination, and synaptic connections, and decrease cellular apoptosis (141, 145147). Transplantation of hUCB is associated with reduced levels of cleaved-caspase-3 protein in hypoxic-ischemic newborn rats, indicative of reduced apoptosis, with BDNF identified as playing 
a role in inhibition of apoptosis and inflammation (141). Further, hUCB cell administration after hypoxia-ischemia increases expression of Tie-2 and occludin proteins, and increases expression of VEGF, indicating that UCB transplantation may increase endogenous angiogenesis and improved BBB integrity within the damaged brain. In vivo, MSCs provide trophic neuroprotection following injury by secreting physical tissue scaffold to surrounding tissues, while UCB-CD34+ cell transplantation enhances functional recovery and reduces both infarction and apoptosis in a rat model of spinal cord injury, mediated by the production of both VEGF and GDNF (148). UCB-derived CD133+ cells promote a threefold improvement in axonal regrowth, a 35\% reduction in apoptosis and vascular and neuronal protection following hypoxia on organ co-culture of brain motor cortex cells and spinal cord from postnatal day 3 rats, suggesting that the trophic effects from CD133+ cells contributes to neuroprotection (149).

Hypoxia-ischemia stimulates endogenous proliferation of NPCs (150). However, if an insult is severe, brain damage still occurs, and the restorative proliferation of NPCs may be ameliorated, with activated NPCs failing to survive to mature neurons $(150,151)$ or differentiating into astrocytes (152). Recently UCBMNC transplantation has been shown to promote the proliferation of endogenous NPCs, and reduce glial differentiation, an action mediated via the Sonic Hedgehog signaling pathway, resulting in the alleviation of brain injury in hypoxic-ischemic neonatal rats (137). These results support the ability of UCB cells to respond to insult with paracrine and trophic actions, initiating a regenerative environment mediated by resident cell populations within the brain.

\section{PRETERM BRAIN INJURY ANIMAL MODELS AND CELL THERAPY}

The majority of experimental studies described above that have investigated the neuroprotective actions of hUCB have been undertaken in rodent models of neonatal (term) hypoxic-ischemic brain injury $(119,120,122,127,133-139)$. Injury to the human brain at the time of term birth induced by hypoxia-ischemia predominantly causes deep gray matter neuronal injury within the basal ganglia and hippocampus, together with injury to neighboring white matter - this is appropriately reflected in rodent and large animal studies of term hypoxia-ischemia. However, this distribution of injury is quite different in preterm WMI, reflecting susceptibility and region-specific effects following hypoxia-ischemia and other insults as brain maturation progresses.

Animal models exploring the injury profile and mechanisms of preterm pre-oligodendrocyte and WMI, have utilized either an hypoxic-ischemic insult, or exposure to LPS-induced inflammation. Excitotoxicity models such as administration of excitatory amino acid agonists quinolinic acid and ibotenate have also been used $(26,153)$. It is important to note that preterm infants mostly suffer hypoxic-ischemic insults that are subacute or chronic, in contrast to term infants where HIE is principally due to an acute severe insult (154). Irrespective of which experimental insult is utilized, the maturational age of the CNS is critical (26). In addition, the choice of species is important. It is well described that induction of predominant WMI is problematic in rats and mice due to the different CNS anatomy of rodents that, besides being non-gyrencephalic and having a different vascular anatomy, demonstrates a much lower white/gray matter ratio than in humans. In contrast, the pattern of WMI in rabbits, cats, dogs, and sheep has a distribution and morphological appearance closer to that of human preterm brain injury induced by either hypoxia-ischemia or LPS administration $(26,59)$. The fetal rabbit brain myelinates with a similar perinatal time course to the human, and maturation of oligodendrocytes begins antenatally (155). In utero, hypoxia-ischemia to the preterm rabbit fetus causes postnatal hypertonic motor deficits that resembles CP, making rabbits a very good model for postnatal behavioral studies (156). Many further studies have been undertaken utilizing fetal sheep models of preterm WMI because of their abundance of cerebral white matter, their anatomic similarities to the preterm infant, and an ability to monitor the systemic and brain response to insult $(37,59,157)$. However, because of cost, availability of antibodies/sequence data and genetically modified animals, rodent WMI studies are valued as complementary models (26). To date, only hAECs have been examined in a non-rodent (fetal sheep) model of preterm WMI. Yawno and colleagues demonstrated that administration of hAECs suppressed the up-regulation of activated microglia, and reduced gray and WMI in response to LPS in preterm fetal sheep (88) (Table 2).

\section{PRETERM BRAIN INJURY AND UMBILICAL CORD BLOOD}

Hall and colleagues demonstrated that in postnatal day 2 rats, intravenous hUCB-MNC administration preserves white matter structures following an hypoxic-ischemic insult. This timeframe corresponds to the period of white matter vulnerability in human preterm infants between 24 and 30 weeks of gestational age (158). Specifically, IV infusion of hUCB-MNCs at $48 \mathrm{~h}$ post-ischemia reduced WMI based on quantification of myelin basic protein. A direct protective effect of UCB-MNCs on oligodendrocyte injury induced by oxygen/glucose deprivation (OGD), which produces hypoxic-ischemic-like injury in vitro, was also identified (158). Although the data are limited, it appears that hUCB-MNCs have therapeutic potential for the protection of oligodendrocytes and thereby prevention of WMI in a premature rat model of ischemia.

\section{ANTIEPILEPTIC EFFECTS OF UMBILICAL CORD BLOOD}

The incidence of seizures in very low birth weight infants is $5.6 \%$, while the occurrence in those infants identified as having PVL is $18.7 \%(159,160)$. Seizures are typically observed in more severe cases of PVL and those born at lower gestational ages and birth weights $(159,160)$. Recent studies demonstrate the antiepileptic actions of hUCB-MNCs. Transplantation of hUCBMNCs 90 min after the onset of status epilepticus in rats, induced by lithium and pilocarpine chloride, protected against neuronal loss in the hippocampus for up to 300 days. Additionally, MNCtransplanted rats had reduced frequency and duration of recurrent seizures, suggesting early administration could protect against the establishment of epilepsy (161). Furthermore in a single case of an infant with infantile spasms (West syndrome) and Xlinked $\mathrm{T} / \mathrm{B}+\mathrm{NK}$-severe combined immunodeficiency, allogeneic UCB transplantation together with topiramate and immunemodulating agents (corticosteroids, intravenous immunoglobulin, 
Table 2 | Outcome of cell-based interventions in preterm brain injury

\begin{tabular}{|c|c|c|c|c|c|c|c|c|c|c|c|c|}
\hline \multirow[t]{2}{*}{ Cell type } & \multirow{2}{*}{$\begin{array}{l}\text { Animal model } \\
\text { Injury type }\end{array}$} & \multicolumn{3}{|c|}{ Administration } & \multicolumn{2}{|c|}{ Engraftment } & \multicolumn{2}{|c|}{ Histology assessments } & \multicolumn{2}{|c|}{ Functional assessments } & \multirow[t]{2}{*}{ Others } & \multirow[t]{2}{*}{ Reference } \\
\hline & & Timing & Dose & Route & Days & Results & Days & Outcomes & Days & Outcomes & & \\
\hline hUCB-MNCs & $\begin{array}{l}\text { P2 rats, } \\
\text { MCAO }\end{array}$ & $\begin{array}{l}48 \mathrm{~h} \text { after } \\
\text { stroke }\end{array}$ & $1 \times 10^{6}$ cells & IV & NA & NA & 4 days & $\begin{array}{l}\text { Reduced white matter } \\
\text { damage }\end{array}$ & NA & NA & $\begin{array}{l}\text { UCB-MNCs directly } \\
\text { reduced apoptosis of } \\
\text { oligodendrocytes } \\
\text { cultured under oxygen } \\
\text { glucose deprivation } \\
\text { in vitro }\end{array}$ & $\begin{array}{l}\text { Hall } 2008 \\
\text { (158) }\end{array}$ \\
\hline hUCB-MNCs & $\begin{array}{l}\text { P5 rats, } \\
\text { excitotoxicity } \\
\text { (ibotenate) }\end{array}$ & $\begin{array}{l}\text { within } 6 \mathrm{~h} \text { or } \\
24 \mathrm{~h} \text { after } \\
\text { injection }\end{array}$ & $\begin{array}{l}1 \times 10^{6} \text { or } 10^{7} \\
\text { cells }\end{array}$ & IP or IV & 5 days & $\begin{array}{l}\text { No cells } \\
\text { detected }\end{array}$ & 5 days & $\begin{array}{l}\text { No changes in lesion } \\
\text { size, microglial } \\
\text { activation, astrogliosis, } \\
\text { or cell proliferation. } \\
\text { Increased white matter } \\
\text { damage with increased } \\
\text { microglial activation by } \\
\text { ip administration }\end{array}$ & NA & NA & & $\begin{array}{l}\text { Dalous } \\
2013(89)\end{array}$ \\
\hline $\begin{array}{l}\text { hUC-MSCs } \\
\text { (Passage 3) }\end{array}$ & $\begin{array}{l}\text { P3 rats, HI } \\
240 \mathrm{~min}\end{array}$ & $\begin{array}{l}0,1,2 \text { days } \\
\text { after } \mathrm{HI} \text {, once } \\
\text { a day }\end{array}$ & $\begin{array}{l}1 \times 10^{6} \text { cells, } \\
3 \text { times }\end{array}$ & IP & $24 \mathrm{~h}$ & $\begin{array}{l}\text { Cells migrated } \\
\text { mainly toward } \\
\text { the injured } \\
\text { hemisphere }\end{array}$ & 7,18 days & $\begin{array}{l}\text { Increased mature } \\
\text { oligodendrocytes } \\
\text { counts. Decreased } \\
\text { astrocytosis and } \\
\text { microglial activation }\end{array}$ & 27 days & $\begin{array}{l}\text { Improved } \\
\text { exploratory } \\
\text { behavior, mental } \\
\text { stress and motor } \\
\text { function }\end{array}$ & & $\begin{array}{l}\text { Zhu } 2014 \\
\text { (174) }\end{array}$ \\
\hline hUCB-MSCs & $\begin{array}{l}\text { P4 rats, blood } \\
\text { injection into } \\
\text { lateral } \\
\text { ventricle }\end{array}$ & P6 & $1 \times 10^{5}$ cells & IVen & NA & NA & 28 days & $\begin{array}{l}\text { Improvements of } \\
\text { corpus callosal } \\
\text { thickness and myelin } \\
\text { basic protein expression } \\
\text { reduction. Attenuation } \\
\text { of astrogliosis and cell } \\
\text { death }\end{array}$ & 28 days & $\begin{array}{l}\text { Improved } \\
\text { behavioral tests } \\
\text { (negative, geotaxis } \\
\text { test and rotarod } \\
\text { test) }\end{array}$ & $\begin{array}{l}\text { Attenuation of } \\
\text { post-hemorrhagic } \\
\text { hydrocephalus } \\
\text { development by MRI. } \\
\text { Decreased } \\
\text { inflammatory cytokines } \\
\text { expression in CSF } \\
(\mathrm{IL}-1 \alpha \text {, IL-1 } 1 \beta \text {, IL-6, and } \\
\text { TNF- } \alpha \text { ) }\end{array}$ & $\begin{array}{l}\text { Ahn } 2013 \\
\text { (121) }\end{array}$ \\
\hline hAECs & $\begin{array}{l}117 \text { days GA } \\
\text { fetal sheep, } \\
\text { LPS }\end{array}$ & $\begin{array}{l}0,6 \text { and } 12 \mathrm{~h} \\
\text { after LPS }\end{array}$ & $\begin{array}{l}\text { IT } 1.8 \times 10^{8} \\
\text { cells, or IV } \\
9 \times 10^{7} \text { cells, } \\
\text { or IT } \\
9 \times 10^{7}+\mathrm{IV} \\
9 \times 10^{7} \text { cells }\end{array}$ & $7 d$ & $\begin{array}{l}\text { Cells were } \\
\text { detected in } 2 \\
\text { of } 14 \text { fetal } \\
\text { brains }\end{array}$ & 7 days & $\begin{array}{l}\text { Decreased activated } \\
\text { microglia in the } \\
\text { cortex, subcortical } \\
\text { and periventricular } \\
\text { white matter. } \\
\text { Decreased } \\
\text { apoptosis in the } \\
\text { cortex and } \\
\text { periventricular white } \\
\text { matter }\end{array}$ & NA & & & & $\begin{array}{l}\text { Yawno } \\
2013(88)\end{array}$ \\
\hline
\end{tabular}

CSF, cerebral spinal fluid; GA, gestational age; HI, hypoxic-ischemia (unilateral ligatiion of the carotid artery followed by 6\% oxygen systemic hypoxia); hAECs, human amnion epithelial cells; hUCB-MNCs, human umbilical cord-mononuclear cells; IP, intraperitoneal; IT, intrathecal; IV, intravenous; IVen, intraventricular; MCAO, middle cerebral artery occlusion; MSCs, mesenchymal cells; MRI, magnetic resonance imaging; NA, not applicable; P, postnatal day; UC, umbilical cord; IL, interleukin; LPS, lipopolysaccharide; TNF-a, tumor necrosis factor-a. 
and tacrolimus) improved seizures, possibly contributed by an immuno-modulatory effect of UCB-MNCs (162).

\section{SUPPRESSION OF EXCITOTOXICITY BY UMBILICAL CORD BLOOD}

Suppression of excitotoxicity is a further important subject of investigation for protecting the developing brain. The potential therapeutic effects of stem cells in animal models of excitotoxic brain injury have been examined using the $N$-methyl-D-aspartate receptor agonist, quinolinic acid, to induce apoptosis and cleaved caspase- 3 and excitotoxic damage in the neocortex, hippocampus, striatum, white matter, and subventricular zone, in the newborn mouse brain. Injection of human embryonic germ cell-derived NPCs partially restores the complement of striatal neurons, with engraftment of the transplanted cells in injured sites and their differentiation into neuronal and glial cells (163). In contrast, intra-peritoneal and intravenous hUCB-MNCs administration could not promote brain repair in ibotenate-induced excitotoxic brain lesions in neonatal rats. The authors of this recent study did, however, suggest that the intra-peritoneal injection of high amounts of hUCB-MNCs may have aggravated WMI, possibly due to systemic inflammation (89).

\section{ANTIOXIDANT EFFECTS OF UMBILICAL CORD BLOOD}

There is increasing evidence that stem cells, especially young cells, possess antioxidant potential, which may then contribute to anti-apoptotic effects (164-166). A recent paper showed that hUCB-NPCs, a neuronal phenotype differentiated from collagenadherent hUCB-MNCs, induced neuroprotection via an antioxidant effect, decreasing free radical levels by $95 \%$ (167). Human MSCs in vitro also scavenge oxygen and nitrogen free radicals, constitutively express antioxidant enzymes, and themselves are highly resistant to oxidative stress-induced death (166). It is still unclear whether cells derived from UCB can mediate tissue oxidative stress in vivo. Since oxidative stress is known to play an important role in the progression of brain injury in preterm infants, this is a crucial consideration for the ability of UCB-MNCs to mediate the progression of preterm brain injury.

\section{VASCULAR DEVELOPMENT, INTRAVENTRICULAR HEMORRHAGE, AND UMBILICAL CORD BLOOD}

Preterm infants are highly vulnerable to IVH due to their maturation-dependent vascular vulnerability, localized to the area of the periventricular germinal matrix and possibly in part due to a coagulation system deficit of prematurity $(9,168)$. Preterm infants predominantly develop IVH in the first week after birth (169). While grades 1 and 2 IVH cause little neurological harm, $>50 \%$ of infants with severe IVH (grades 3 and 4 ) die or develop post-hemorrhagic hydrocephalus ( $\mathrm{PHH})$. The incidence of severe IVH in very preterm infants ranges from $<5$ to $20 \%$ (170). IVH is observed in $25 \%$ of infants with PVL and worsens WMI by increasing the amount of iron that combines with harmful free radicals and inflammatory cytokines to exacerbate injury $(171,172)$. The incidence of IVH has declined with current neonatal intensive care practices, but it remains an important problem, for which there is no targeted treatment (170). A recent paper demonstrated that intraventricular administration of hUCB-MSCs attenuates brain damage after severe IVH in newborn rats. The anti-inflammatory effects of MSCs (i.e., reducing the expression of inflammatory cytokines, such as IL- $1 \alpha$, IL-1 $\beta$, IL- 6 , and TNF- $\alpha$ ) were hypothesized to contribute to the prevention of ventricular dilation and neuroprotection (121). In adult rats, IV administration of hUCBMNCs also showed amelioration of neurologic deficits associated with intra-cerebral hemorrhage (173).

\section{OLIGODENDROCYTES, MYELIN DEFICITS, AND UMBILICAL CORD BLOOD}

Loss of pre-oligodendrocytes and hypomyelination are the principal characteristics of preterm WMI and therefore protection of oligodendrocyte lineage cells must be central to the development of any neuroprotective strategies for the preterm brain. Recently, Zhu and colleagues have shown that hUC-MSCs increase mature oligodendrocyte number and improve long-term functional outcomes following hypoxia-ischemia in postnatal day 3 rats, with engraftment of cells at lesion sites (174). It will, however be important to further elucidate whether UCB stem cells can reduce pre-oligodendrocyte injury and thereby restore myelination in fetal or neonatal animal models of WMI. There is some indirect evidence that UCB cell populations may infer benefit to oligodendrocytes and myelination. The rare but serious genetic disorders termed leukodystrophies cause degeneration of myelin and progressive neurological deterioration and, to date, the only known treatment option for leukodystrophies is early transplantation of HSCs (175). Experimentally, spontaneous myelin mutants have been used to study potential therapies. The most commonly used myelin mutant in transplant experiments is the shiverer mouse, which has a mutation in the myelin basic protein gene, and has been extensively used to study myelination by exogenous cell transplantation, including HSCs, MSCs, and oligodendrocytes progenitor cells (OPCs). OPCs can be isolated, differentiated, and expanded from both fresh and cryopreserved UCB $(176,177)$ offering a potential treatment option, and lay the foundations for future studies in this research field.

\section{CLINICAL TRIALS FOR CEREBRAL PALSY}

There are currently a number of clinical trials listed, or recently completed, for treatment of children with established CP. A pilot study from Hanyang University Medical Center, Republic of Korea examined 20 children aged 2-10 years with clinical CP, who were born either preterm or term, and administered peripheral autologous UCB-MNCs. Neurodevelopmental outcomes and neuroimaging studies were conducted up to 24 weeks after UCB administration, and compared with a pre-infusion baseline. Functional improvements were demonstrated in $25 \%$ of patients, and improvements in brain imaging outcomes were also noted in children with neurodevelopmental recovery. Side effects were identified in $25 \%$ of participants during infusion, treated successfully with antihistamines and hydration. Although not powered to demonstrate statistical benefit, the study showed the potential and safety of autologous UCB-MNC treatment in children (178). Between 2009 and 2012, Duke University in the USA treated 23 term newborns identified with HIE soon after birth with autologous UCB administration. The study was able to demonstrate feasibility and safety of autologous UCB re-administration in 
combination with hypothermia, targeting UCB administration at $6 \mathrm{~h}$. Neurodevelopmental outcomes were recorded at 1 year of age, however, a greater number of babies will be required to appropriately assess functional outcomes (179). Duke University is continuing to recruit for a larger study of autologous UCB administration for children with established spastic CP.

\section{USE AND EFFICACY OF COMBINATION THERAPIES}

A recent clinical study has assessed allogeneic UCB administered in combination with erythropoietin (EPO - itself the subject of neuroprotective trials), cyclosporine (an immunosuppressant), and rehabilitation therapy at Bundang CHA Hospital, Republic of Korea. Ninety-six children with CP aged 10 months to 10 years were treated with UCB cells, and improved cognitive and motor function were observed in all groups, including placebo, but with greater improvements in UCB + EPO children (180). Due to its design, this study does not separate the neuroprotective effects of EPO from UCB. However, combination therapy, which targets different mechanisms and therapeutic windows, may be a useful approach to treat preterm infants because of their multifactorial causes of injury and the inherent difficulties with identifying a therapeutic time frame in these infants. Indeed, ganglioside and mannitol have been shown to enhance the neuroprotective benefits of hUCB-MNCs and hUC-MSCs treatments following neonatal asphyxia in pre-clinical studies $(130,138)$. In contrast, despite recent promising neuroprotective outcomes of EPO in preterm cohort (181), routine clinical use of EPO, especially by high-dose, has always been hampered by its risk for retinopathy of prematurity (182). Melatonin, a powerful antioxidant shown to protect the developing brain by reducing oxidative stress following hypoxia-ischemia, with an absence of side effects, may be a candidate for co-administration with UCB (183). In term infants with HIE, hypothermia has been standard neuroprotective therapy for a number of years (184), and combination treatment of moderate hypothermia with MSCs significantly improves neuronal survival and mitochondrial activity after OGD exposure in vitro (185). Clinically, Cotten and colleagues recently showed that hypothermia and autologous UCB combination treatment is feasible and safe in term infants with HIE (179), and reflects that any treatment for term HIE must be considered in the context of therapeutic hypothermia. However, in very preterm and extremely preterm infants hypothermia is not currently recommended and may increase the risk of complications or death (186). A phase 1 clinical study of selected head cooling for preterm infants, born 3235 weeks gestation, with neonatal HIE has recently been completed [NCT00620711], and the results are awaited with interest.

Other types of stem and stem-like cells may also be used for the combination therapy with UCB. UC, in addition to UCB, provides an abundant and non-invasive source of MSCs. These cells are neuroprotective in hypoxic-ischemic brain injury, and share similar in vitro immunosuppressive properties with bone marrowand UCB-derived MSCs as well as mediating monocyte function to suppress T cell proliferation $(130,187)$. Importantly, hUC-MSCs also protect oligodendrocytes, reduce astrogliosis, and improve long-term functional outcomes in a model of preterm postnatal day 3 rats hypoxia-ischemia (174). Moreover, hUC-MSCs undergo successful cell expansion using animal serum-free culture medium, thereby removing safety concerns of animal-to-human viral transmission, further encouraging their potential for clinical application $(188,189)$. hAECs may present a useful therapy in combination with UCB, hypothermia, or alternate therapies. The proven anti-inflammatory properties of hAECs appear a principal mechanism to reduce preterm brain injury (88). They display both embryonic and pluripotent stem cells with abundant quantity, do not express $\mathrm{MHC}$ class molecules so have low immunogenicity, and do not form teratomas (190). Furthermore, the ready availability of hAECs without the need of expansion may enable them to be used for early autologous transplantation for preterm brain injury $(88,188,189)$, with or without combination therapies.

\section{OPTIMAL TIMING OF TRANSPLANTATION OF UMBILICAL CORD BLOOD}

Recent experimental studies have been aimed at identifying the therapeutic window for UCB therapy. In adult rats who underwent middle cerebral artery occlusion-induced stroke, intravenous administration of hUCB-MNCs within $72 \mathrm{~h}$ resulted in an early functional recovery with lesion improvement, however cell administration at $120 \mathrm{~h}$ provided only minor functional recovery, and treatment at 14 days did not show any benefit (132). Whether a similar result can be obtained in an autologous or allogeneic setting is unknown. However, given that one of the primary benefits of UCB cells is their anti-inflammatory actions, it is likely that early intervention may be of greater benefit. Indeed, current ongoing clinical trials for neonatal HIE by National University Hospital, Singapore, and Duke University, USA are giving autologous UCB within the first 3 and 14 days, respectively after term birth asphyxia (NCT01649648 and NCT00593242). However, in preterm infants, it is difficult to know the timing of WMI that results in cystic PVL or diffuse WMI $(9,184,191)$ and therefore either combination therapies, or cell preparations with multiple benefits would be most appropriate.

\section{CLINICAL TRIALS FOR PRETERM BRAIN INJURY}

No trials of neuroprotective UCB for use in treating WMI in preterm infants are currently registered in humans. A significant challenge in the design of a clinical trial for preterm infants is the question of which UCB cells to administer? As described above, it is becoming apparent that the type and quantity of specific cell types differs in preterm UCB from that in term UCB. A dose-response effect of UCB therapy for neonatal hypoxia-ischemia has been demonstrated $(133,192)$, but it is unclear whether a therapeutic quantity of cells can be derived from preterm UCB as the volumes obtained are low (see Umbilical Cord Blood above). Further to this, the ability to expand preterm UCB cells is not yet well described.

In preterm infants, as also discussed above, the timing of the onset, and chronic progression of WMI is usually not known. It is also not known whether to administer UCB cells before or after brain injury is identified. Administration following the identification of brain injury may provide better outcomes than administration in later childhood, due to the plasticity of the developing brain; although the evidence for this both in pre-clinical studies and clinical trials is sparse. In contrast, as cystic PVL or diffuse WMI tend to develop over days to weeks after birth (72, 169), early postnatal UCB administration "before defining 
brain damage" in preterm and extremely low birth weight infants may be more efficacious. Indeed, two clinical trials administering autologous UCB to preterm infants in the first 5 or 14 days postdelivery, aiming to examine feasibility and efficacy for a variety of preterm complications, are currently underway (NCT02050971 and NCT01121328). However, in preterm infants susceptible to WMI at least until 32 weeks or more gestational age, a single administration of cells might not span an adequate period of brain protection. Thus, the need for repeated dose administration and expansion of UCB samples are further exemplified in a preterm cohort. Recently described in vivo cell tracking methodology using MRI, which enables the tracking of migration and distribution of magnetically labeled cells in tissues, may be useful for optimizing the time course for UCB treatment (193).

\section{CONCLUSION}

Taking into account the similarities and differences in preterm versus term brain injury, and limitations to date in stem cell studies for preterm WMI, it is apparent that a number of considerations apply before UCB treatment could be extended to infants born preterm. The clear advantage of undertaking UCB administration in a preterm cohort is the relative plasticity of the developing brain in immature infants, and potential for regeneration. However, there are current disadvantages that must be overcome. Studies to date suggest that early cell administration post-injury achieves favorable therapeutic outcomes, but a current lack of sensitive diagnostic tools and inability to accurately determine the onset of preterm brain injury remains problematic. Work to define the most appropriate time for therapeutic intervention is needed. Additionally, the specific cells present in UCB responsible for brain protection are not yet characterized and the complications of pregnancy that are often co-morbidities with preterm birth, such as uteroplacental inflammation or IUGR, may alter the cellular composition of UCB. A handful of published work suggests that preterm UCB cell number, cell total population and cell maturity is different to that in term UCB, which may not provide the expected benefit that has been observed using term hUCB in experimental animal and clinical studies. It is therefore currently not known whether autologous or allogeneic UCB cell administration would confer optimal benefit in a preterm cohort, or whether expansion of specific cell types should be considered and pursued. Thus it remains that UCB holds strong promise for the treatment of preterm brain injury in the neonate, but fundamental questions must be answered with appropriately designed experimental animal and clinical studies prior to large-scale randomized clinical trials for preterm brain injury.

\section{ACKNOWLEDGMENTS}

The authors wish to thank support from Inner Wheel Australia and the Victorian Government's Operational Infrastructure Support Program.

\section{REFERENCES}

1. Costeloe KL, Hennessy EM, Haider S, Stacey F, Marlow N, Draper ES. Short term outcomes after extreme preterm birth in England: comparison of two birth cohorts in 1995 and 2006 (the EPICure studies). BMJ (2012) 345(7886):e7976. doi:10.1136/bmj.e7976

2. Blencowe H, Cousens S, Oestergaard MZ, Chou D, Moller AB, Narwal R, et al. National, regional, and worldwide estimates of preterm birth rates in the year
2010 with time trends since 1990 for selected countries: a systematic analysis and implications. Lancet (2012) 379(9832):2162-72. doi:10.1016/S01406736(12)60820-4

3. Wen SW, Smith G, Yang Q, Walker M. Epidemiology of preterm birth and neonatal outcome. Semin Fetal Neonatal Med (2004) 9(6):429-35. doi:10.1016/ j.siny.2004.04.002

4. Blencowe H, Cousens S, Chou D, Oestergaard M, Say L, Moller AB, et al. Born too soon: the global epidemiology of 15 million preterm births. Reprod Health (2013) 10(Suppl):1. doi:10.1186/1742-4755-10-S1-S2

5. Larroque B, Ancel PY, Marret S, Marchand L, André M, Arnaud C, et al. Neurodevelopmental disabilities and special care of 5-year-old children born before 33 weeks of gestation (the EPIPAGE study): a longitudinal cohort study. Lancet (2008) 371(9615):813-20. doi:10.1016/S0140-6736(08)60380-3

6. Robertson CMT, Watt MJ, Yasui Y. Changes in the prevalence of cerebral palsy for children born very prematurely within a population-based program over 30 years. J Am Med Assoc (2007) 297(24):2733-40. doi:10.1001/jama.297.24.2733

7. Pharoah POD, Platt MJ, Cooke T. The changing epidemiology of cerebral palsy. Arch Dis Child Fetal Neonatal Ed (1996) 75(3):F169-73. doi:10.1136/ fn.75.3.F169

8. Thorngren-Jerneck K, Herbst A. Perinatal factors associated with cerebral palsy in children born in Sweden. Obstet Gynecol (2006) 108(6):1499-505. doi:10.1097/01.AOG.0000247174.27979.6b

9. Volpe JJ. Neurology of the Newborn. Philadelphia: Elsevier Health Sciences (2008).

10. Behrman RE, Adashi EY, Allen MC, Caruso RL, Culhane J, Schetter CD, et al. Committee on understanding premature birth and assuring healthy outcomes. In: Behrman RE, Butler AS, editors. Preterm Birth: Causes, Consequences, and Prevention. Washington DC: Institute of Medicine of the National Academies (2007). p. 1-772.

11. Honeycutt A, Dunlap L, Chen H, Homsi G, Grosse S, Schendel D. Economic costs associated with mental retardation, cerebral palsy, hearing loss, and vision impairment United States, 2003. MMWR Morb Mortal Wkly Rep (2004) 53(3):57-9.

12. Back SA. Perinatal white matter injury: the changing spectrum of pathology and emerging insights into pathogenetic mechanisms. Ment Retard Dev Disabil Res Rev (2006) 12(2):129-40. doi:10.1002/mrdd.20107

13. Oka A, Belliveau MJ, Rosenberg PA, Volpe JJ. Vulnerability of oligodendroglia to glutamate: pharmacology, mechanisms, and prevention. J Neurosci (1993) 13(4):1441-53.

14. Fern R, Möller T. Rapid ischemic cell death in immature oligodendrocytes: a fatal glutamate release feedback loop. J Neurosci (2000) 20(1):34-42.

15. Dammann O, Leviton A. Maternal intrauterine infection, cytokines, and brain damage in the preterm newborn. Pediatr Res (1997) 42(1):1-8. doi:10.1203/ 00006450-199707000-00001

16. Segovia KN, McClure M, Moravec M, Luo NL, Wan Y, Gong X, et al. Arrested oligodendrocyte lineage maturation in chronic perinatal white matter injury. Ann Neurol (2008) 63(4):520-30. doi:10.1002/ana.21359

17. Buser JR, Maire J, Riddle A, Gong X, Nguyen T, Nelson K, et al. Arrested preoligodendrocyte maturation contributes to myelination failure in premature infants. Ann Neurol (2012) 71(1):93-109. doi:10.1002/ana.22627

18. Volpe JJ. Cerebral white matter injury of the premature infant More common than you think. Pediatrics (2003) 112(1 I):176-80. doi:10.1542/peds.112.1.176

19. Krägeloh-Mann I, Petersen D, Hagberg G, Vollmer B, Hagberg B, Michaelis R. Bilateral spastic cerebral palsy - MRI pathology and origin. Analysis from a representative series of 56 cases. Dev Med Child Neurol (1995) 37(5):379-97. doi:10.1111/j.1469-8749.1995.tb12022.x

20. Whitaker AH, Van RossemR, Feldman JF, Schonfeld IS, Pinto-Martin JA, Tore $\mathrm{C}$, et al. Psychiatric outcomes in low-birth-weight children at age 6 years: relation to neonatal cranial ultrasound abnormalities. Arch Gen Psychiatry (1997) 54(9):847-56. doi:10.1001/archpsyc.1997.01830210091012

21. Koerte I, Pelavin P, Kirmess B, Fuchs T, Berweck S, Laubender RP, et al. Anisotropy of transcallosal motor fibres indicates functional impairment in children with periventricular leukomalacia. Dev Med Child Neurol (2011) 53(2):179-86. doi:10.1111/j.1469-8749.2010.03840.x

22. Hoon AHJr, Stashinko EE, Nagae LM, Lin DD, Keller J, Bastian A, et al. Sensory and motor deficits in children with cerebral palsy born preterm correlate with diffusion tensor imaging abnormalities in thalamocortical pathways. Dev Med Child Neurol (2009) 51(9):697-704. doi:10.1111/j.1469-8749.2009. 03306.x 
23. Khwaja O, Volpe JJ. Pathogenesis of cerebral white matter injury of prematurity. Arch Dis Child Fetal Neonatal Ed (2008) 93(2):F153-61. doi:10.1136/adc. 2006.108837

24. Takashima S, Tanaka K. Development of cerebrovascular architecture and its relationship to periventricular leukomalacia. Arch Neurol (1978) 35(1):11-6. doi:10.1001/archneur.1978.00500250015003

25. Ballabh P, Braun A, Nedergaard M. Anatomic analysis of blood vessels in germinal matrix, cerebral cortex, and white matter in developing infants. Pediatr Res (2004) 56(1):117-24. doi:10.1203/01.PDR.0000130472.30874.FF

26. Hagberg H, Peebles D, Mallard C. Models of white matter injury: comparison of infectious, hypoxic-ischemic, and excitotoxic insults. Ment Retard Dev Disabil Res Rev (2002) 8(1):30-8. doi:10.1002/mrdd.10007

27. Pierson CR, Folkerth RD, Billiards SS, Trachtenberg FL, Drinkwater ME, Volpe JJ, et al. Gray matter injury associated with periventricular leukomalacia in the premature infant. Acta Neuropathol (2007) 114(6):619-31. doi:10.1007/s00401-007-0295-5

28. Volpe JJ. Neurobiology of periventricular leukomalacia in the premature infant. Pediatr Res (2001) 50(5):553-62. doi:10.1203/00006450-200111000-00003

29. Yoon BH, Park CW, Chaiworapongsa T. Intrauterine infection and the development of cerebral palsy. BJOG (2003) 110(Suppl 20):124-7. doi:10.1046/j. 1471-0528.2003.00063.x

30. Volpe JJ, Kinney HC, Jensen FE, Rosenberg PA. The developing oligodendrocyte: key cellular target in brain injury in the premature infant. Int J Dev Neurosci (2011) 29(4):423-40. doi:10.1016/j.ijdevneu.2011.02.012

31. Arai Y, Deguchi K, Mizuguchi M, Takashima S. Expression of beta-amyloid precursor protein in axons of periventricular leukomalacia brains. Pediatr Neurol (1995) 13(2):161-3. doi:10.1016/0887-8994(95)00149-A

32. Meng SZ, Arai Y, Deguchi K, Takashima S. Early detection of axonal and neuronal lesions in prenatal-onset periventricular leukomalacia. Brain Dev (1997) 19(7):480-4. doi:10.1016/S0387-7604(97)00068-5

33. Rezaie P, Dean A. Periventricular leukomalacia, inflammation and white matter lesions within the developing nervous system. Neuropathology (2002) 22(3):106-32. doi:10.1046/j.1440-1789.2002.00438.x

34. Kinney HC, Back SA. Human oligodendroglial development: relationship to periventricular leukomalacia. Semin Pediatr Neurol (1998) 5(3):180-9. doi:10.1016/S1071-9091(98)80033-8

35. Sheldon RA, Chuai J, Ferriero DM. A rat model for hypoxic-ischemic brain damage in very premature infants. Biol Neonate (1996) 69(5):327-41. doi:10. $1159 / 000244327$

36. Stoll G, Jander S, Schroeter M. Detrimental and beneficial effects of injuryinduced inflammation and cytokine expression in the nervous system. Adv Exp Med Biol (2002) 513:87-113.

37. Gunn AJ, Bennet L. Fetal hypoxia insults and patterns of brain injury: insights from animal models. Clin Perinatol (2009) 36(3):579-93. doi:10.1016/j.clp. 2009.06.007

38. Bennet L, Tan S, Van den Heuij L, Derrick M, Groenendaal F, van Bel F, et al. Cell therapy for neonatal hypoxia-ischemia and cerebral palsy. Ann Neurol (2012) 71(5):589-600. doi:10.1002/ana.22670

39. Lorek A, Takei Y, Cady EB, Wyatt JS, Penrice J, Edwards AD, et al. Delayed ('secondary') cerebral energy failure after acute hypoxia-ischemia in the newborn piglet: continuous 48-hour studies by phosphorus magnetic resonance spectroscopy. Pediatr Res (1994) 36(6):699-706. doi:10.1203/00006450199412000-00003

40. Narumiya S, Ohno M, Tanaka N, Yamano T, Shimada M. Enhanced expression of full-length TrkB receptors in young rat brain with hypoxic/ischemic injury. Brain Res (1998) 797(2):278-86. doi:10.1016/S0006-8993(98)00385-0

41. Stone BS, Zhang J, Mack DW, Mori S, Martin LJ, Northington FJ. Delayed neural network degeneration after neonatal hypoxia-ischemia. Ann Neurol (2008) 64(5):535-46. doi:10.1002/ana.21517

42. Barrett RD, Bennet L, Davidson J, Dean JM, George S, Emerald BS, et al. Destruction and reconstruction: hypoxia and the developing brain. Birth Defects Res C Embryo Today (2007) 81(3):163-76. doi:10.1002/bdrc.20095

43. Haynes RL, Baud O, Li J, Kinney HC, Volpe JJ, Folkerth DR. Oxidative and nitrative injury in periventricular leukomalacia: a review. Brain Pathol (2005) 15(3):225-33. doi:10.1111/j.1750-3639.2005.tb00525.x

44. Haynes RL, Folkerth RD, Keefe RJ, Sung I, Swzeda LI, Rosenberg PA, et al. Nitrosative and oxidative injury to premyelinating oligodendrocytes in periventricular leukomalacia. J Neuropathol Exp Neurol (2003) 62(5):441-50.
45. Back SA, Luo NL, Mallinson RA, O’Malley JP, Wallen LD, Frei B, et al. Selective vulnerability of preterm white matter to oxidative damage defined by F2-isoprostanes. Ann Neurol (2005) 58(1):108-20. doi:10.1002/ana.20530

46. Polglase GR, Miller SL, Barton SK, Kluckow M, Gill AW, Hooper SB, et al. Respiratory support for premature neonates in the delivery room: effects on cardiovascular function and the development of brain injury. Pediatr Res (2014) 75(6):682-8. doi:10.1038/pr.2014.40

47. Yoon BH, Jun JK, Romero R, Park KH, Gomez R, Choi JH, et al. Amniotic fluid inflammatory cytokines (interleukin-6, interleukin-1 $\beta$, and tumor necrosis factor- $\alpha$ ), neonatal brain white matter lesions, and cerebral palsy. Am JObstet Gynecol (1997) 177(1):19-26. doi:10.1016/S0002-9378(97)70432-0

48. Yoon BH, Romero R, Yang SH, Jun JK, Kim IO, Choi JH, et al. Interleukin-6 concentrations in umbilical cord plasma are elevated in neonates with white matter lesions associated with periventricular leukomalacia. Am J Obstet Gynecol (1996) 174(5):1433-40. doi:10.1016/S0002-9378(96)70585-9

49. Yoon BH, Romero R, Kim CJ, Jun JK, Gomez R, Choi JH, et al. Amniotic fluid interleukin-6: a sensitive test for antenatal diagnosis of acute inflammatory lesions of preterm placenta and prediction of perinatal morbidity. Am J Obstet Gynecol (1995) 172(3):960-70. doi:10.1016/0002-9378(95)90028-4

50. Goldenberg RL, Culhane JF, Iams JD, Romero R. Epidemiology and causes of preterm birth. Lancet (2008) 371(9606):75-84. doi:10.1016/S0140-6736(08) 60074-4

51. Resch B, Vollaard E, Maurer U, Haas J, Rosegger H, Müller W. Risk factors and determinants of neurodevelopmental outcome in cystic periventricular leucomalacia. Eur J Pediatr (2000) 159(9):663-70. doi:10.1007/PL00008403

52. Bejar R, Wozniak P, Allard M, Benirschke K, Vaucher Y, Coen R, et al. Antenatal origin of neurologic damage in newborn infants. I. preterm infants. Am J Obstet Gynecol (1988) 159(2):357-63. doi:10.1016/S0002-9378(88) 80084-X

53. Silveira RC, Procianoy RS, Dill JC, da Costa CS. Periventricular leukomalacia in very low birth weight preterm neonates with high risk for neonatal sepsis. J Pediatr (2008) 84(3):211-6. doi:10.2223/JPED.1777

54. Resch B, Neubauer K, Hofer N, Resch E, Maurer U, Haas J, et al. Episodes of hypocarbia and early-onset sepsis are risk factors for cystic periventricular leukomalacia in the preterm infant. Early Hum Dev (2012) 88(1):27-31. doi:10.1016/j.earlhumdev.2011.06.011

55. Lehnardt S. Innate immunity and neuroinflammation in the CNS: the role of microglia in toll-like receptor-mediated neuronal injury. Glia (2010) 58(3):253-63. doi:10.1002/glia.20928

56. Lehnardt S, Lachance C, Patrizi S, Lefebvre S, Follett PL, Jensen FE, et al. The toll-like receptor TLR4 is necessary for lipopolysaccharide-induced oligodendrocyte injury in the CNS. J Neurosci (2002) 22(7):2478-86.

57. Billiards SS, Haynes RL, Folkerth RD, Trachtenberg FL, Liu LG, Volpe JJ, et al. Development of microglia in the cerebral white matter of the human fetus and infant. J Comp Neurol (2006) 497(2):199-208. doi:10.1002/cne.20991

58. Jurewicz A, Matysiak M, Tybor K, Kilianek L, Raine CS, Selmaj K. Tumour necrosis factor-induced death of adult human oligodendrocytes is mediated by apoptosis inducing factor. Brain (2005) 128(11):2675-88. doi:10.1093/brain/ awh627

59. Peebles DM, Miller S, Newman JP, Scott R, Hanson MA. The effect of systemic administration of lipopolysaccharide on cerebral haemodynamics and oxygenation in the 0.65 gestation ovine fetus in utero. BJOG (2003) 110(8):735-43. doi:10.1111/j.1471-0528.2003.02152.x

60. Duncan JR, Cock ML, Suzuki K, Scheerlinck JP, Harding R, Rees SM. Chronic endotoxin exposure causes brain injury in the ovine fetus in the absence of hypoxemia. J Soc Gynecol Investig (2006) 13(2):87-96. doi:10.1016/j.jsgi.2005. 12.003

61. Li N, Karin M. Is NF-kappaB the sensor of oxidative stress? FASEB J (1999) 13(10):1137-43.

62. Duncan JR, Cock ML, Scheerlinck JP, Westcott KT, McLean C, Harding $\mathrm{R}$, et al. White matter injury after repeated endotoxin exposure in the preterm ovine fetus. Pediatr Res (2002) 52(6):941-9. doi:10.1203/00006450200212000-00021

63. Kaukola T, Herva R, Perhomaa M, Pääkkö E, Kingsmore S, Vainionpää L, et al. Population cohort associating chorioamnionitis, cord inflammatory cytokines and neurologic outcome in very preterm, extremely low birth weight infants. Pediatr Res (2006) 59(3):478-83. doi:10.1203/01.pdr.0000182596. 66175.ee 
64. Crowley PA. Antenatal corticosteroid therapy: a meta-analysis of the randomized trials, 1972 to 1994. Am J Obstet Gynecol (1995) 173(1):322-35. doi:10.1016/0002-9378(95)90222-8

65. Robertson NJ, Tan S, Groenendaal F, van Bel F, Juul SE, Bennet L, et al. Which neuroprotective agents are ready for bench to bedside translation in the newborn infant? Jof Pediatr (2012) 160(4):544-52. doi:10.1016/j.jpeds.2011.12.052

66. Salmeen KE, Jelin AC, Thiet MP. Perinatal neuroprotection. F1000Prime Rep (2014) 6:6. doi:10.12703/P6-6

67. Low JA. Determining the contribution of asphyxia to brain damage in the neonate. J Obstet Gynaecol Res (2004) 30(4):276-86. doi:10.1111/j.1447-0756. 2004.00194.x

68. Rees S, Harding R, Walker D. The biological basis of injury and neuroprotection in the fetal and neonatal brain. Int J Dev Neurosci (2011) 29(6):551-63. doi:10.1016/j.ijdevneu.2011.04.004

69. Rees S, Inder T. Fetal and neonatal origins of altered brain development. Early Hum Dev (2005) 81(9):753-61. doi:10.1016/j.earlhumdev.2005.07.004

70. Okumura A, Hayakawa F, Kato T, Itomi K, Maruyama K, Ishihara N, et al. Hypocarbia in preterm infants with periventricular leukomalacia: the relation between hypocarbia and mechanical ventilation. Pediatrics (2001) 107(3):469-75. doi:10.1542/peds.107.3.469

71. Wiswell TE, Graziani LJ, Kornhauser MS, Stanley C, Merton DA, McKee L, et al. Effects of hypocarbia on the development of cystic periventricular leukomalacia in premature infants treated with high-frequency jet ventilation. Pediatrics (1996) 98(5):918-24.

72. Volpe JJ. Brain injury in the premature infant: overview of clinical aspects, neuropathology, and pathogenesis. Semin Pediatr Neurol (1998) 5(3):135-51. doi:10.1016/S1071-9091(98)80030-2

73. Vohr BR. Neurodevelopmental outcomes of extremely preterm infants. Clin Perinatol (2014) 41(1):241-55. doi:10.1016/j.clp.2013.09.003

74. Thomson JA, Itskovitz-Eldor J, Shapiro SS, Waknitz MA, Swiergiel JJ, Marshall VS, et al. Embryonic stem cell lines derived from human blastocysts. Science (1998) 282(5391):1145-7. doi:10.1126/science.282.5391.1145

75. Roy NS, Cleren C, Singh SK, Yang L, Beal MF, Goldman SA. Functional engraftment of human ES cell-derived dopaminergic neurons enriched by coculture with telomerase-immortalized midbrain astrocytes. Nat Med (2006) 12(11):1259-68. doi:10.1038/nm1495

76. Takahashi K, Tanabe K, Ohnuki M, Narita M, Ichisaka T, Tomoda K, et al. Induction of pluripotent stem cells from adult human fibroblasts by defined factors. Cell (2007) 131(5):861-72. doi:10.1016/j.cell.2007.11.019

77. Knoepfler PS. Deconstructing stem cell tumorigenicity: a roadmap to safe regenerative medicine. Stem Cells (2009) 27(5):1050-6. doi:10.1002/stem.37

78. Payne N, Siatskas C, Bernard CCA. The promise of stem cell and regenerative therapies for multiple sclerosis. J Autoimmun (2008) 31(3):288-94. doi:10.1016/j.jaut.2008.04.002

79. Ilancheran S, Michalska A, Peh G, Wallace EM, Pera M, Manuelpillai U. Stem cells derived from human fetal membranes display multilineage differentiation potential. Biol Reprod (2007) 77(3):577-88. doi:10.1095/biolreprod.106. 055244

80. Phuc PV, Ngoc VB, Lam DH, Tam NT, Viet PQ, Ngoc PK. Isolation of three important types of stem cells from the same samples of banked umbilical cord blood. Cell Tissue Bank (2012) 13(2):341-51. doi:10.1007/s10561-011-9262-4

81. Castillo-Melendez M, Yawno T, Jenkin G, Miller SL. Stem cell therapy to protect and repair the developing brain: a review of mechanisms of action of cord blood and amnion epithelial derived cells. Front Neurosci (2013) 7:194. doi:10.3389/fnins.2013.00194

82. Payne NL, Sun G, McDonald C, Layton D, Moussa L, Emerson-Webber A, et al. Distinct immunomodulatory and migratory mechanisms underpin the therapeutic potential of human mesenchymal stem cells in autoimmune demyelination. Cell Transplant (2013) 22(8):1409-25. doi:10.3727/096368912X657620

83. Gordon D, Pavlovska G, Glover CP, Uney JB, Wraith D, Scolding NJ. Human mesenchymal stem cells abrogate experimental allergic encephalomyelitis after intraperitoneal injection, and with sparse CNS infiltration. Neurosci Lett (2008) 448(1):71-3. doi:10.1016/j.neulet.2008.10.040

84. Li Y, Chen J, Chen XG, Wang L, Gautam SC, Xu YX, et al. Human marrow stromal cell therapy for stroke in rat: neurotrophins and functional recovery. Neurology (2002) 59(4):514-23. doi:10.1212/WNL.59.4.514

85. Liu T, Wu J, Huang Q, Hou Y, Jiang Z, Zang S, et al. Human amniotic epithelial cells ameliorate behavioral dysfunction and reduce infarct size in the rat middle cerebral artery occlusion model. Shock (2008) 29(5):603-11. doi:10.1097/SHK.0b013e318157e845

86. Murphy S, Lim R, Dickinson H, Acharya R, Rosli S, Jenkin G, et al. Human amnion epithelial cells prevent bleomycin-induced lung injury and preserve lung function. Cell Transplant (2011) 20(6):909-23. doi:10.3727/ 096368910X543385

87. Tropea KA, Leder E, Aslam M, Lau AN, Raiser DM, Lee JH, et al. Bronchioalveolar stem cells increase after mesenchymal stromal cell treatment in a mouse model of bronchopulmonary dysplasia. Am J Physiol Lung Cell Mol Physiol (2012) 302(9):L829-37. doi:10.1152/ajplung.00347.2011

88. Yawno T, Schuilwerve J, Moss TJ, Vosdoganes P, Westover AJ, Afandi E, et al. Human amnion epithelial cells reduce fetal brain injury in response to intrauterine inflammation. Dev Neurosci (2013) 35(2-3):272-82. doi:10.1159/ 000346683

89. Dalous J, Pansiot J, Pham H, Chatel P, Nadaradja C, D'Agostino I, et al. Use of human umbilical cord blood mononuclear cells to prevent perinatal brain injury: a preclinical study. Stem Cells Dev (2013) 22(1):169-79. doi:10.1089/scd.2012.0183

90. Levine AD, Wolf LE. The roles and responsibilities of physicians in patients' decisions about unproven stem cell therapies. J Law Med Ethics (2012) 40(1):122-34. doi:10.1111/j.1748-720X.2012.00650.x

91. Solves P, López M, Mirabet V, Blanquer A, Roig R, Perales A. Characteristics of umbilical cord blood units collected from preterm deliveries. Gynecol Obstet Invest (2009) 68(3):181-5. doi:10.1159/000232382

92. Rogers I, Casper RF. Umbilical cord blood stem cells. Best Pract Res Clin Obstet Gynaecol (2004) 18(6):893-908. doi:10.1016/j.bpobgyn.2004.06.004

93. Rocha V, Wagner JEJr, Sobocinski KA, Klein JP, Zhang MJ, Horowitz MM, et al. Graft-versus-host disease in children who have received a cord-blood or bone marrow transplant from an HLA-identical sibling. eurocord and international bone marrow transplant registry working committee on alternative donor and stem cell sources. N Engl J Med (2000) 342(25):1846-54. doi:10.1056/NEJM200006223422501

94. Vaziri H, Dragowska W, Allsopp RC, Thomas TE, Harley CB, Lansdorp PM. Evidence for a mitotic clock in human hematopoietic stem cells: loss of telomeric DNA with age. Proc Natl Acad Sci U S A (1994) 91(21):9857-60. doi:10.1073/pnas.91.21.9857

95. Nakahata T, Ogawa M. Hemopoietic colony-forming cells in umbilical cord blood with extensive capability to generate mono- and multi-potential hemopoietic progenitors. J Clin Invest (1982) 70(6):1324-8. doi:10.1172/JCI110734

96. Tiwari A, Tursky ML, Kirkland MA, Pande G. Expansion of human hematopoietic stem/progenitor cells on decellularized matrix scaffolds. Curr Protoc Stem Cell Biol (2014) 1(Suppl 28). doi:10.1002/9780470151808.sc01c15s28

97. Coldwell KE, Lee SJ, Kean J, Khoo CP, Tsaknakis G, Smythe J, et al. Effects of obstetric factors and storage temperatures on the yield of endothelial colony forming cells from umbilical cord blood. Angiogenesis (2011) 14(3):381-92. doi:10.1007/s10456-011-9222-4

98. Tolar J, Hippen KL, Blazar BR. Immune regulatory cells in umbilical cord blood: T regulatory cells and mesenchymal stromal cells. Br J Haematol (2009) 147(2):200-6. doi:10.1111/j.1365-2141.2009.07781.x

99. Kern S, Eichler H, Stoeve J, Klüter H, Bieback K. Comparative analysis of mesenchymal stem cells from bone marrow, umbilical cord blood, or adipose tissue. Stem Cells (2006) 24(5):1294-301. doi:10.1634/stemcells.2005-0342

100. Manca MF, Zwart I, Beo J, Palasingham R, Jen LS, Navarrete R, et al. Characterization of mesenchymal stromal cells derived from full-term umbilical cord blood. Cytotherapy (2008) 10(1):54-68. doi:10.1080/14653240701732763

101. Jain A, Mathur N, Jeevashankar M, Mukhopadhyay A, Agarwal R, Deorari $\mathrm{AK}$, et al. Does mesenchymal stem cell population in umbilical cord blood vary at different gestational periods? Indian J Pediatr (2013) 80(5):375-9. doi:10.1007/s12098-012-0844-3

102. El-Badri NS, Hakki A, Saporta S, Liang X, Madhusodanan S, Willing AE, et al. Cord blood mesenchymal stem cells: potential use in neurological disorders. Stem Cells Dev (2006) 15(4):497-506. doi:10.1089/scd.2006.15.497

103. Abbott NJ, Patabendige AA, Dolman DE, Yusof SR, Begley DJ. Structure and function of the blood-brain barrier. Neurobiol Dis (2010) 37(1):13-25. doi:10.1016/j.nbd.2009.07.030

104. Hristov M, Erl W, Weber PC. Endothelial progenitor cells: mobilization, differentiation, and homing. Arterioscler Thromb Vasc Biol (2003) 23(7):1185-9. doi:10.1161/01.ATV.0000073832.49290.B5 
105. Larrivée B, Niessen K, Pollet I, Corbel SY, Long M, Rossi FM, et al. Minimal contribution of marrow-derived endothelial precursors to tumor vasculature. J Immunol (2005) 175(5):2890-9. doi:10.4049/jimmunol.175.5.2890

106. Sakaguchi S. Naturally arising Foxp3-expressing CD25+CD4+ regulatory T cells in immunological tolerance to self and non-self. Nat Immunol (2005) 6(4):345-52. doi:10.1038/ni1178

107. Takahata Y, Nomura A, Takada H, Ohga S, Furuno K, Hikino S, et al. CD25+CD4+ T cells in human cord blood: an immunoregulatory subset with naive phenotype and specific expression of forkhead box p3 (Foxp3) gene. Exp Hematol (2004) 32(7):622-9. doi:10.1016/j.exphem.2004.03.012

108. Hoffmann P, Edinger M. CD4+CD25+ regulatory T cells and graft-versus-host disease. Semin Hematol (2006) 43(1):62-9. doi:10.1053/j.seminhematol.2005. 09.006

109. Meister B, Tötsch M, Mayr A, Widschwendter M, Huter O, Sperl W. Identification of CD34+ cord blood cells and their subpopulations in preterm and term neonates using three-color flow cytometry. Biol Neonate (1994) 66(5):272-9. doi:10.1159/000244117

110. Ballen KK, Wilson M, Wuu J, Ceredona AM, Hsieh C, Stewart FM, et al. Bigger is better: maternal and neonatal predictors of hematopoietic potential of umbilical cord blood units. Bone Marrow Transplant (2001) 27(1):7-14. doi:10.1038/sj.bmt.1702729

111. Cervera A, Lillo R, García-Sánchez F, Madero L, Madero R, Vicario JL. Flow cytometric assessment of hematopoietic cell subsets in cryopreserved preterm and term cord blood, influence of obstetrical parameters, and availability for transplantation. Am J Hematol (2006) 81(6):397-410. doi:10.1002/ ajh.20598

112. Gasparoni A, Ciardelli L, Avanzini MA, Bonfichi M, di Mario M, Piazzi G, et al. Immunophenotypic changes of fetal cord blood hematopoietic progenitor cells during gestation. Pediatr Res (2000) 47(6):825-9. doi:10.1203/00006450200006000-00024

113. Baker CD, Ryan SL, Ingram DA, Seedorf GJ, Abman SH, Balasubramaniam V. Endothelial colony-forming cells from preterm infants are increased and more susceptible to hyperoxia. Am J Respir Crit Care Med (2009) 180(5):454-61. doi:10.1164/rccm.200901-0115OC

114. Monga R, Buck S, Sharma P, Thomas R, Chouthai NS. Effect of preeclampsia and intrauterine growth restriction on endothelial progenitor cells in human umbilical cord blood. J Matern Fetal Neonatal Med (2012) 25(11):2385-9. doi:10.3109/14767058.2012.697228

115. Javed MJ, Mead LE, Prater D, Bessler WK, Foster D, Case J, et al. Endothelial colony forming cells and mesenchymal stem cells are enriched at different gestational ages in human umbilical cord blood. Pediatr Res (2008) 64(1):68-73. doi:10.1203/PDR.0b013e31817445e9

116. Lim R, Chan ST, Tan JL, Mockler JC, Murphy SV, Wallace EM. Preterm human amnion epithelial cells have limited reparative potential. Placenta (2013) 34(6):486-92. doi:10.1016/j.placenta.2013.03.010

117. Dirix V, Vermeulen F, Mascart F. Maturation of CD4+ regulatory T lymphocytes and of cytokine secretions in infants born prematurely. J Clin Immunol (2013) 33(6):1126-33. doi:10.1007/s10875-013-9911-4

118. Mukhopadhyay D, Weaver L, Tobin R, Henderson S, Beeram M, Newell-Rogers $\mathrm{MK}$, et al. Intrauterine growth restriction and prematurity influence regulatory T cell development in newborns. J Pediatr Surg (2014) 49(5):727-32. doi:10.1016/j.jpedsurg.2014.02.055

119. Xia G, Hong X, Chen X, Lan F, Zhang G, Liao L. Intracerebral transplantation of mesenchymal stem cells derived from human umbilical cord blood alleviates hypoxic ischemic brain injury in rat neonates. J Perinat Med (2010) 38(2):215-21. doi:10.1515/JPM.2010.021

120. Kim ES, Ahn SY, Im GH, Sung DK, Park YR, Choi SH, et al. Human umbilical cord blood-derived mesenchymal stem cell transplantation attenuates severe brain injury by permanent middle cerebral artery occlusion in newborn rats. Pediatr Res (2012) 72(3):277-84. doi:10.1038/pr.2012.71

121. Ahn SY, Chang YS, Sung DK, Sung SI, Yoo HS, Lee JH, et al. Mesenchymal stem cells prevent hydrocephalus after severe intraventricular hemorrhage. Stroke (2013) 44(2):497-504. doi:10.1161/STROKEAHA.112.679092

122. Tsuji M, Taguchi A, Ohshima M, Kasahara Y, Sato Y, Tsuda H, et al. Effects of intravenous administration of umbilical cord blood CD34+ cells in a mouse model of neonatal stroke. Neuroscience (2014) 263:148-58. doi:10.1016/ j.neuroscience.2014.01.018

123. Iskander A, Knight RA, Zhang ZG, Ewing JR, Shankar A, Varma NR, et al. Intravenous administration of human umbilical cord blood-derived AC133+ endothelial progenitor cells in rat stroke model reduces infarct volume: magnetic resonance imaging and histological findings. Stem Cells Transl Med (2013) 2(9):703-14. doi:10.5966/sctm.2013-0066

124. Womble TA, Green S, Shahaduzzaman M, Grieco J, Sanberg PR, Pennypacker $\mathrm{KR}$, et al. Monocytes are essential for the neuroprotective effect of human cord blood cells following middle cerebral artery occlusion in rat. Mol Cell Neurosci (2014) 59:76-84. doi:10.1016/j.mcn.2014.01.004

125. Shahaduzzaman M, Golden JE, Green S, Gronda AE, Adrien E, Ahmed A, et al. A single administration of human umbilical cord blood $\mathrm{T}$ cells produces long-lasting effects in the aging hippocampus. Age (2013) 35(6):2071-87. doi:10.1007/s11357-012-9496-5

126. Saporta S, Kim JJ, Willing AE, Fu ES, Davis CD, Sanberg PR. Human umbilical cord blood stem cells infusion in spinal cord injury: engraftment and beneficial influence on behavior. J Hematother Stem Cell Res (2003) 12(3):271-8. doi:10.1089/152581603322023007

127. Meier C, Middelanis J, Wasielewski B, Neuhoff S, Roth-Haerer A, Gantert $\mathrm{M}$, et al. Spastic paresis after perinatal brain damage in rats is reduced by human cord blood mononuclear cells. Pediatr Res (2006) 59(2):244-9. doi:10.1203/01.pdr.0000197309.08852.f5

128. Gornicka-Pawlak elB, Janowski M, Habich A, Jablonska A, Drela K, Kozlowska $\mathrm{H}$, et al. Systemic treatment of focal brain injury in the rat by human umbilical cord blood cells being at different level of neural commitment. Acta Neurobiol Exp (2011) 71(1):46-64.

129. Prockop DJ. "Stemness" does not explain the repair of many tissues by mesenchymal stem/multipotent stromal cells (MSCs). Clin Pharmacol Ther (2007) 82(3):241-3. doi:10.1038/sj.clpt.6100313

130. Zhang X, Zhang Q, Li W, Nie D, Chen W, Xu C, et al. Therapeutic effect of human umbilical cord mesenchymal stem cells on neonatal rat hypoxicischemic encephalopathy. J Neurosci Res (2014) 92(1):35-45. doi:10.1002/jnr. 23304

131. Seo JH, Cho SR. Neurorestoration induced by mesenchymal stem cells: potential therapeutic mechanisms for clinical trials. Yonsei Med J (2012) 53(6):1059-67. doi:10.3349/ymj.2012.53.6.1059

132. Boltze J, Schmidt UR, Reich DM, Kranz A, Reymann KG, Strassburger M, et al. Determination of the therapeutic time window for human umbilical cord blood mononuclear cell transplantation following experimental stroke in rats. Cell Transplant (2012) 21(6):1199-211. doi:10.3727/096368911X589609

133. de Paula S, Greggio S, Marinowic DR, Machado DC, DaCosta JC. The doseresponse effect of acute intravenous transplantation of human umbilical cord blood cells on brain damage and spatial memory deficits in neonatal hypoxiaischemia. Neuroscience (2012) 210:431-41. doi:10.1016/j.neuroscience.2012. 03.009

134. Pimentel-Coelho PM, Magalhães ES, Lopes LM, deAzevedo LC, Santiago MF, Mendez-Otero R. Human cord blood transplantation in a neonatal rat model of hypoxic-ischemic brain damage: functional outcome related to neuroprotection in the striatum. Stem Cells Dev (2010) 19(3):351-8. doi:10.1089/scd. 2009.0049

135. Geissler M, Dinse HR, Neuhoff S, Kreikemeier K, Meier C. Human umbilical cord blood cells restore brain damage induced changes in rat somatosensory cortex. PLoS One (2011) 6(6):e20194. doi:10.1371/journal.pone.0020194

136. Wasielewski B, Jensen A, Roth-Härer A, Dermietzel R, Meier C. Neuroglial activation and $\mathrm{Cx} 43$ expression are reduced upon transplantation of human umbilical cord blood cells after perinatal hypoxic-ischemic injury. Brain Res (2012) 1487:39-53. doi:10.1016/j.brainres.2012.05.066

137. Wang X, Zhao Y, Wang X. Umbilical cord blood cells regulate the differentiation of endogenous neural stem cells in hypoxic ischemic neonatal rats via the hedgehog signaling pathway. Brain Res (2014) 1560:18-26. doi:10.1016/j.brainres.2014.02.019

138. Yasuhara T, Hara K, Maki M, Xu L, Yu G, Ali MM, et al. Mannitol facilitates neurotrophic factor up-regulation and behavioural recovery in neonatal hypoxicischaemic rats with human umbilical cord blood grafts. J Cell Mol Med (2010) 14(4):914-21. doi:10.1111/j.1582-4934.2008.00671.x

139. Bae SH, Kong TH, Lee HS, Kim KS, Hong KS, Chopp M, et al. Long-lasting paracrine effects of human cord blood cells on damaged neocortex in an animal model of cerebral palsy. Cell Transplant (2012) 21(11):2497-515. doi:10.3727/096368912X640457

140. Rice Iii JE, Vannucci RC, Brierley JB. The influence of immaturity on hypoxic-ischemic brain damage in the rat. Ann Neurol (1981) 9(2):131-41. doi:10.1002/ana.410090206 
141. Rosenkranz K. Transplantation of human umbilical cord blood cells mediated beneficial effects on apoptosis, angiogenesis and neuronal survival after hypoxic-ischemic brain injury in rats. Cell Tissue Res (2012) 348(3):429-38. doi:10.1007/s00441-012-1401-0

142. Newman MB, Willing AE, Manresa JJ, Sanberg CD, Sanberg PR. Cytokines produced by cultured human umbilical cord blood (HUCB) cells: implications for brain repair. Exp Neurol (2006) 199(1):201-8. doi:10.1016/j.expneurol.2006. 04.001

143. Neuhoff S, Moers J, Rieks M, Grunwald T, Jensen A, Dermietzel R, et al. Proliferation, differentiation, and cytokine secretion of human umbilical cord blood-derived mononuclear cells in vitro. Exp Hematol (2007) 35(7):1119-31. doi:10.1016/j.exphem.2007.03.019

144. Nakase T, Söhl G, Theis M, Willecke K, Naus CC. Increased apoptosis and inflammation after focal brain ischemia in mice lacking connexin 43 in astrocytes. Am J Pathol (2004) 164(6):2067-75. doi:10.1016/S0002-9440(10) 63765-0

145. Bachstetter AD, Pabon MM, Cole MJ, Hudson CE, Sanberg PR, Willing AE, et al. Peripheral injection of human umbilical cord blood stimulates neurogenesis in the aged rat brain. BMC Neurosci (2008) 9:22. doi:10.1186/1471-2202-9-22

146. Liao W, Zhong J, Yu J, Xie J, Liu Y, Du L, et al. Therapeutic benefit of human umbilical cord derived mesenchymal stromal cells in intracerebral hemorrhage rat: implications of anti-inflammation and angiogenesis. Cell Physiol Biochem (2009) 24(3-4):307-16. doi:10.1159/000233255

147. Rosenkranz K, Meier C. Umbilical cord blood cell transplantation after brain ischemia-from recovery of function to cellular mechanisms. Ann Anat (2011) 193(4):371-9. doi:10.1016/j.aanat.2011.03.005

148. Kao CH, Chen SH, Chio CC, Lin MT. Human umbilical cord blood-derived CD34+ cells may attenuate spinal cord injury by stimulating vascular endothelial and neurotrophic factors. Shock (2008) 29(1):49-55. doi:10.1097/shk. 0b013e31805cddce

149. Tanaka N, Kamei N, Nakamae T, Yamamoto R, Ishikawa M, Fujiwara H, et al. CD133+ cells from human umbilical cord blood reduce cortical damage and promote axonal growth in neonatal rat organ co-cultures exposed to hypoxia. Int J Dev Neurosci (2010) 28(7):581-7. doi:10.1016/j.ijdevneu.2010.07.232

150. Brazel CY, Nuñez JL, Yang Z, Levison SW. Glutamate enhances survival and proliferation of neural progenitors derived from the subventricular zone. Neuroscience (2005) 131(1):55-65. doi:10.1016/j.neuroscience.2004.10.038

151. Ikeda T, Iwai M, Hayashi T, Nagano I, Shogi M, Ikenoue T, et al. Limited differentiation to neurons and astroglia from neural stem cells in the cortex and striatum after ischemia/hypoxia in the neonatal rat brain. Am J Obstet Gynecol (2005) 193(3):849-56. doi:10.1016/j.ajog.2005.01.029

152. Horie N, So K, Moriya T, Kitagawa N, Tsutsumi K, Nagata I, et al. Effects of oxygen concentration on the proliferation and differentiation of mouse neural stem cells in vitro. Cell Mol Neurobiol (2008) 28(6):833-45. doi:10.1007/ s10571-007-9237-y

153. Saliba E, Marret S. Cerebral white matter damage in the preterm infant: pathophysiology and risk factors. Semin Neonatol (2001) 6(2):121-33. doi:10.1053/ siny.2001.0043

154. Sie LT, van der Knaap MS, Oosting J, de Vries LS, Lafeber HN, Valk J. MR patterns of hypoxic-ischemic brain damage after prenatal, perinatal or postnatal asphyxia. Neuropediatrics (2000) 31(3):128-36. doi:10.1055/s-2000-7496

155. Derrick M, Drobyshevsky A, Ji X, Tan S. A model of cerebral palsy from fetal hypoxia-ischemia. Stroke (2007) 38(2 Pt 2):731-5. doi:10.1161/01.STR. 0000251445.94697.64

156. Derrick M, Luo NL, Bregman JC, Jilling T, Ji X, Fisher K, et al. Preterm fetal hypoxia-ischemia causes hypertonia and motor deficits in the neonatal rabbit: a model for human cerebral palsy? J Neurosci (2004) 24(1):24-34. doi:10.1523/JNEUROSCI.2816-03.2004

157. Back SA, Riddle A, Dean J, Hohimer AR. The instrumented fetal sheep as a model of cerebral white matter injury in the premature infant. Neurotherapeutics (2012) 9(2):359-70. doi:10.1007/s13311-012-0108-y

158. Hall AA, Guyer AG, Leonardo CC, Ajmo CTJr, Collier LA, Willing AE, et al. Human umbilical cord blood cells directly suppress ischemic oligodendrocyte cell death. J Neurosci Res (2009) 87(2):333-41. doi:10.1002/jnr.21857

159. Kohelet D, Shochat R, Lusky A, Reichman B; Israel Neonatal Network. Risk factors for seizures in very low birthweight infants with periventricular leukomalacia. J Child Neurol (2006) 21(11):965-70. doi:10.1177/08830738060210111301

160. Kohelet D, Shochat R, Lusky A, Reichman B; Israel Neonatal Network. Risk factors for neonatal seizures in very low birthweight infants: population-based survey. J Child Neurol (2004) 19(2):123-8. doi:10.1177/ 08830738040190020701

161. Costa-Ferro ZS, de Borba Cunha F, de Freitas Souza BS, Leal MM, da Silva AA, de Bellis Kühn TI, et al. Antiepileptic and neuroprotective effects of human umbilical cord blood mononuclear cells in a pilocarpine-induced epilepsy model. Cytotechnology (2014) 66(2):193-9. doi:10.1007/s10616-0139557-3

162. Motobayashi M, Inaba Y, Fukuyama T, Kurata T, Niimi T, Saito S, et al. Successful treatment for west syndrome with severe combined immunodeficiency. Brain Dev (2014). doi:10.1016/j.braindev.2014.01.012

163. Mueller D, Shamblott MJ, Fox HE, Gearhart JD, Martin LJ. Transplanted human embryonic germ cell-derived neural stem cells replace neurons and oligodendrocytes in the forebrain of neonatal mice with excitotoxic brain damage. J Neurosci Res (2005) 82(5):592-608. doi:10.1002/jnr.20673

164. Madhavan L, Ourednik V, Ourednik J. Increased "vigilance" of antioxidant mechanisms in neural stem cells potentiates their capability to resist oxidative stress. Stem Cells (2006) 24(9):2110-9. doi:10.1634/stemcells.2006-0018

165. Ito K, Hirao A, Arai F, Takubo K, Matsuoka S, Miyamoto K, et al. Reactive oxygen species act through p38 MAPK to limit the lifespan of hematopoietic stem cells. Nat Med (2006) 12(4):446-51. doi:10.1038/nm1388

166. Valle-Prieto A, Conget PA. Human mesenchymal stem cells efficiently manage oxidative stress. Stem Cells Dev (2010) 19(12):1885-93. doi:10.1089/scd. 2010.0093

167. Arien-Zakay H, Lecht S, Bercu MM, Tabakman R, Kohen R, Galski H, et al. Neuroprotection by cord blood neural progenitors involves antioxidants, neurotrophic and angiogenic factors. Exp Neurol (2009) 216(1):83-94. doi:10.1016/j.expneurol.2008.11.006

168. Andrew M, Paes B, Milner R, Johnston M, Mitchell L, Tollefsen DM, et al. Development of the human coagulation system in the healthy premature infant. Blood (1988) 72(5):1651-7.

169. Miller SP, Ferriero DM, Leonard C, Piecuch R, Glidden DV, Partridge JC, et al. Early brain injury in premature newborns detected with magnetic resonance imaging is associated with adverse early neurodevelopmental outcome. J Pediatr (2005) 147(5):609-16. doi:10.1016/j.jpeds.2005.06.033

170. Heuchan AM, Evans N, Henderson Smart DJ, Simpson JM. Perinatal risk factors for major intraventricular haemorrhage in the Australian and New Zealand neonatal network, 1995-97. Arch Dis Child Fetal Neonatal Ed (2002) 86(2):F86-90. doi:10.1136/fn.86.2.F86

171. Dommergues MA, Gallego J, Evrard P, Gressens P. Iron supplementation aggravates periventricular cystic white matter lesions in newborn mice. Eur J Paediatrc Neurol (1998) 2(6):313-8. doi:10.1016/S1090-3798(98)80006-8

172. Gould SJ, Howard S, Hope PL, Reynolds EO. Periventricular intraparenchymal cerebral haemorrhage in preterm infants: the role of venous infarction. J Pathol (1987) 151(3):197-202. doi:10.1002/path.1711510307

173. Nan Z, Grande A, Sanberg CD, Sanberg PR, Low WC. Infusion of human umbilical cord blood ameliorates neurologic deficits in rats with hemorrhagic brain injury. Ann N Y Acad Sci (2005) 1049:84-96. doi:10.1196/annals.1334.009

174. Zhu LH, Bai X, Zhang N, Wang SY, Li W, Jiang L. Improvement of human umbilical cord mesenchymal stem cell transplantation on glial cell and behavioral function in a neonatal model of periventricular white matter damage. Brain Res (2014) 1563:13-21. doi:10.1016/j.brainres.2014.03.030

175. van Egmond ME, Pouwels PJ, Boelens JJ, Lindemans CA, Barkhof F, Steenwijk $\mathrm{MD}$, et al. Improvement of white matter changes on neuroimaging modalities after stem cell transplant in metachromatic leukodystrophy. JAMA Neurol (2013) 70(6):779-82. doi:10.1001/jamaneurol.2013.629

176. Tracy ET, Zhang CY, Gentry T, Shoulars KW, Kurtzberg J. Isolation and expansion of oligodendrocyte progenitor cells from cryopreserved human umbilical cord blood. Cytotherapy (2011) 13(6):722-9. doi:10.3109/14653249.2011. 553592

177. Chua SJ, Bielecki R, Wong CJ, Yamanaka N, Rogers IM, Casper RF. Neural progenitors, neurons and oligodendrocytes from human umbilical cord blood cells in a serum-free, feeder-free cell culture. Biochem Biophys Res Commun (2009) 379(2):217-21. doi:10.1016/j.bbrc.2008.12.045

178. Lee YH, Choi KV, Moon JH, Jun HJ, Kang HR, Oh SI, et al. Safety and feasibility of countering neurological impairment by intravenous administration of autologous cord blood in cerebral palsy. J Transl Med (2012) 10(1):58. doi:10.1186/1479-5876-10-58

179. Cotten CM, Murtha AP, Goldberg RN, Grotegut CA, Smith PB, Goldstein RF, et al. Feasibility of autologous cord blood cells for infants with 
hypoxic-ischemic encephalopathy. J Pediatr (2014) 164(5):973-9. doi:10.1016/ j.jpeds.2013.11.036

180. Min K, Song J, Kang JY, Ko J, Ryu JS, Kang MS, et al. Umbilical cord blood therapy potentiated with erythropoietin for children with cerebral palsy: a doubleblind, randomized, placebo-controlled trial. Stem Cells (2013) 31(3):581-91. doi:10.1002/stem.1304

181. Leuchter RH, Gui L, Poncet A, Hagmann C, Lodygensky GA, Martin E, et al. Association between early administration of high-dose erythropoietin in preterm infants and brain MRI abnormality at term-equivalent age. JAMA (2014) 312(8):817-24. doi:10.1001/jama.2014.9645

182. Aher SM, Ohlsson A. Late erythropoietin for preventing red blood cell transfusion in preterm and/or low birth weight infants. Cochrane Database Syst Rev (2012) 9:CD004868. doi:10.1002/14651858.CD004868.pub3

183. Miller SL, Yan EB, Castillo-Meléndez M, Jenkin G, Walker DW. Melatonin provides neuroprotection in the late-gestation fetal sheep brain in response to umbilical cord occlusion. Dev Neurosci (2005) 27(2-4):200-10. doi:10.1159/ 000085993

184. Li J, Funato M, Tamai H, Wada H, Nishihara M, Iwamoto H, et al. Predictors of neurological outcome in cooled neonates. Pediatr Int (2013) 55(2):169-76. doi:10.1111/ped.12008

185. Kaneko Y, Tajiri N, Su TP, Wang Y, Borlongan CV. Combination treatment of hypothermia and mesenchymal stromal cells amplifies neuroprotection in primary rat neurons exposed to hypoxic-ischemic-like injury in vitro: role of the opioid system. PLoS One (2012) 7(10):e47583. doi:10.1371/journal.pone. 0047583

186. de Almeida MF, Guinsburg R, Sancho GA, Rosa IR, Lamy ZC, Martinez FE, et al. Hypothermia and early neonatal mortality in preterm infants. J Pediatr (2014) 164(2):271-5. doi:10.1016/j.jpeds.2013.09.049

187. Cutler AJ, Limbani V, Girdlestone J, Navarrete CV. Umbilical cord-derived mesenchymal stromal cells modulate monocyte function to suppress $\mathrm{T}$ cell proliferation. J Immunol (2010) 185(11):6617-23. doi:10.4049/jimmunol.1002239

188. Julavijitphong S, Wichitwiengrat S, Tirawanchai N, Ruangvutilert P, Vantanasiri C, Phermthai T. A xeno-free culture method that enhances Wharton's jelly mesenchymal stromal cell culture efficiency over traditional animal serumsupplemented cultures. Cytotherapy (2014) 16(5):683-91. doi:10.1016/j.jcyt. 2013.07.012

189. Ding Y, Yang H, Feng JB, Qiu Y, Li DS, Zeng Y. Human umbilical cord-derived MSC culture: the replacement of animal sera with human cord blood plasma.
In vitro Cell Dev Biol Anim (2013) 49(10):771-7. doi:10.1007/s11626-0139663-8

190. Murphy S, Rosli S, Acharya R, Mathias L, Lim R, Wallace E, et al. Amnion epithelial cell isolation and characterization for clinical use. Curr Protoc Stem Cell Biol (2010) (Suppl 13):1E.6.1-25. doi:10.1002/9780470151808. sc01e06s13

191. Li J, Kobata K, Kamei Y, Okazaki Y, Nishihara M, Wada H, et al. Nucleated red blood cell counts: an early predictor of brain injury and 2-year outcome in neonates with hypoxic-ischemic encephalopathy in the era of coolingbased treatment. Brain Dev (2014) 36(6):472-8. doi:10.1016/j.braindev.2013. 06.012

192. de Paula S, Vitola AS, Greggio S, de Paula D, Mello PB, Lubianca JM, et al. Hemispheric brain injury and behavioral deficits induced by severe neonatal hypoxia-ischemia in rats are not attenuated by intravenous administration of human umbilical cord blood cells. Pediatr Res (2009) 65(6):631-5. doi:10.1203/PDR.0b013e31819ed5c8

193. Hansen L, Hansen AB, Mathiasen AB, Ng M, Bhakoo K, Ekblond A, et al. Characterisation of mesenchymal stromal cells labeled with ultrasmall superparamagnetic iron-oxide nanoparticles for clinical tracking studies. Scand J Clin Lab Invest (2014) 74(5):437-46. doi:10.3109/00365513.2014.900698

Conflict of Interest Statement: The authors declare that the research was conducted in the absence of any commercial or financial relationships that could be construed as a potential conflict of interest.

Received: 20 July 2014; paper pending published: 19 August 2014; accepted: 19 September 2014; published online: 09 October 2014.

Citation: Li J, McDonald CA, Fahey MC, Jenkin G and Miller SL (2014) Could cord blood cell therapy reduce preterm brain injury? Front. Neurol. 5:200. doi: 10.3389/fneur.2014.00200

This article was submitted to Neuropediatrics, a section of the journal Frontiers in Neurology.

Copyright $\odot 2014 \mathrm{Li}, \mathrm{McD}$ onald, Fahey, Jenkin and Miller. This is an open-access article distributed under the terms of the Creative Commons Attribution License (CC BY). The use, distribution or reproduction in other forums is permitted, provided the original author $(s)$ or licensor are credited and that the original publication in this journal is cited, in accordance with accepted academic practice. No use, distribution or reproduction is permitted which does not comply with these terms. 